\title{
Business model innovation for circular economy and sustainability: A review of approaches
}

Pieroni, Marina P.; McAloone, Tim; Pigosso, Daniela A. C.

Published in:

Journal of Cleaner Production

Link to article, DOI:

10.1016/j.jclepro.2019.01.036

Publication date:

2019

Document Version

Peer reviewed version

Link back to DTU Orbit

Citation (APA):

Pieroni, M. P., McAloone, T., \& Pigosso, D. A. C. (2019). Business model innovation for circular economy and sustainability: A review of approaches. Journal of Cleaner Production, 215, 198-216.

https://doi.org/10.1016/j.jclepro.2019.01.036

\section{General rights}

Copyright and moral rights for the publications made accessible in the public portal are retained by the authors and/or other copyright owners and it is a condition of accessing publications that users recognise and abide by the legal requirements associated with these rights.

- Users may download and print one copy of any publication from the public portal for the purpose of private study or research.

- You may not further distribute the material or use it for any profit-making activity or commercial gain

- You may freely distribute the URL identifying the publication in the public portal

If you believe that this document breaches copyright please contact us providing details, and we will remove access to the work immediately and investigate your claim. 


\section{Accepted Manuscript}

Business model innovation for circular economy and sustainability: A review of approaches

Marina P. Pieroni, Tim McAloone, Daniela A.C. Pigosso

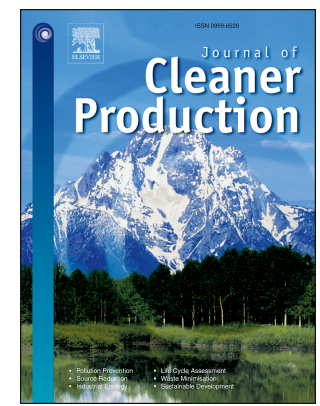

PII:

S0959-6526(19)30042-3

DOI:

https://doi.org/10.1016/j.jclepro.2019.01.036

Reference: JCLP 15423

To appear in: Journal of Cleaner Production

Received Date: 25 September 2018

Revised Date: 3 January 2019

Accepted Date: 5 January 2019

Please cite this article as: Pieroni MP, McAloone T, Pigosso DAC, Business model innovation for circular economy and sustainability: A review of approaches, Journal of Cleaner Production (2019), doi: https:// doi.org/10.1016/j.jclepro.2019.01.036.

This is a PDF file of an unedited manuscript that has been accepted for publication. As a service to our customers we are providing this early version of the manuscript. The manuscript will undergo copyediting, typesetting, and review of the resulting proof before it is published in its final form. Please note that during the production process errors may be discovered which could affect the content, and all legal disclaimers that apply to the journal pertain. 
Business model innovation for circular economy and sustainability: a review of approaches

\author{
Marina P. Pieroni ${ }^{\mathrm{a} *}$, Tim McAloone ${ }^{\mathrm{a}}$, Daniela A. C. Pigosso ${ }^{\mathrm{a}}$
}

${ }^{a}$ Technical University of Denmark (DTU), Department of Mechanical Engineering, Nils Koppels Allé 404 / Room 229, DK- 2800 Kgs. Lyngby

* Corresponding author. Mob: +45 50132114; E-mail: mdpp@dtu.dk 
Business model innovation for circular economy and sustainability: a review of approaches

\section{Introduction}

Sustainability and circular economy (CE) are of growing interest for governments, investors, companies and the civil society. Sustainability envisions a balanced integration of economic performance, social inclusiveness, and environmental resilience, to the benefit of current and future generations (Geissdoerfer et al., 2017a). CE emerged as an umbrella concept in the 2010's (Blomsma and Brennan, 2017), and envisions the achievement of a more resource effective and efficient economic system by intentionally narrowing, slowing and closing materials and energy flows (Bocken et al., 2016; EMF, 2015). CE is often seen as a means to achieving sustainability, but with a narrower focus on the economic and environmental dimensions (Geissdoerfer et al., 2017a). Nevertheless, not all systems (e.g. businesses, value chains) incorporating circular principles are intrinsically more sustainable (Geissdoerfer et al., 2018b).

Enhanced sustainability or circularity requires changes in the way companies generate value, understand and do business. Companies are compelled to interact within an ecosystem of actors, moving from a firmcentric to a network-centric operational logic. This transition requires rethinking their incumbent business models (BM), in order to enable a decoupling of value creation and resource consumption (Bocken et al., 2016). Hence, business model innovation (BMI) towards sustainability and circularity is a fundamental capability for companies.

Research related to the BM concept within the boundaries of sustainability and CE is still recent, with just 10 and 5 years of activities, respectively (Diaz Lopez et al., 2019; Foss and Saebi, 2017; Lüdeke-Freund and Dembek, 2017). As expected, these bodies of knowledge or potential 'emerging' research fields are still in a conceptualization stage and literature is fragmented (Lüdeke-Freund and Dembek, 2017; Merli et al., 2018; Nußholz, 2017). Likewise, the boundaries and synergies between circular and sustainable BMI are not clearly explored (Geissdoerfer et al., 2017a). While researchers are focusing on understanding and describing these fields, practitioners are already being 'pushed' for the transformation of their BMs as a means of embedding circular or sustainability thinking (European Commission, 2018, 2014). Therefore, sustainable and circular BMI approaches have also been proposed in the gray literature by companies, consultancies, governments or NGOs.

Despite the excitement, a shared framework does not yet exist to support researchers/practitioners in need of understanding how to conceptualize, design and implement circular or sustainable BM as a means to solve or avoid environmental or social issues, whilst aiming for economic benefits. In addition, the way in which general BM-related research has evolved might generate confusion in regards to the interpretation of the BM construct (Lüdeke-Freund and Dembek, 2017). Research about conventional BM concepts and BMI has progressed into a more robust body of knowledge over the past 15 years. However, it is still in a consolidation phase, with inconsistencies and conceptual ambiguity associated with multidisciplinary contributions from different research fields and the elusive nature of the BM construct, which allows for interpretative flexibility (Foss and Saebi, 2017; Massa and Tucci, 2014; Wirtz et al., 2016). The BM construct is applied widely and sometimes promiscuously. Many of the proposed approaches for circular or sustainable BMI are inspired by conventional BM theory and consider circular/sustainable BMI as subfields of conventional BMI (Lüdeke-Freund and Dembek, 2017), which to a certain extent inherits the aforementioned lack of consistency. Furthermore, many authors proposing approaches for sustainable and circular BMI try to highlight their differentiation from the conventional stream and assume a positioning of individual 'silos', instead of promoting complementarity or integration of approaches for synergistic gains. Additionally, there is a lack of clarification of where existing tools for conventional BM are sufficient and where new tools are required for embedding circularity or sustainability in BMI (Lüdeke-Freund and Dembek, 2017; Nußholz, 2017). Not only have they assumed a 'silo' positioning regarding conventional stream, but also in relation to each other. Several approaches have been proposed either for circular or sustainable BMI, however few approaches try to address the integrated vision of both concepts (Antikainen and Valkokari, 2016; Geissdoerfer et al., 2018a; Vogtlander et al., 2017). In this dynamic scenario, characterized by an intensive boost of heterogeneous intellectual content in a short period, it is difficult for researchers/practitioners to decide on where to start or which approach to follow. 
This paper attempts to address this challenge by providing an overview of the different approaches for circular or sustainable BMI currently available in literature or in use by practitioners. Using the lens of BMI as a transformational process towards circularity or sustainability, we systematize approaches (i.e. conceptual frameworks, methods and tools) supporting circular or sustainable BMI processes based on a dynamic capabilities view. With this, we attempt to provide greater clarity around how each approach is applied, plus their differences and potential synergies, in order to support the selection of appropriate approaches, identify gaps and promote a unified research agenda.

Our research contributes to the intersection of $\mathrm{CE}$, sustainability and BMI literature, envisioning the academic/practitioner perspectives, and responding to several recent calls for research (Geissdoerfer et al., 2017b; Schaltegger et al., 2016a) by providing:

(1) A systematization of a comprehensive collection of approaches currently available to support BMI towards CE or sustainability (Schaltegger et al., 2016a). While some publications analyze some approaches for sustainable (Breuer et al., 2018; Prendeville and Bocken, 2017; Schoormann et al., 2016) or circular (Nußholz, 2018; Roos and Agarwal, 2015) BMI independently, so far there is no comparative study that takes an in depth look at the approaches for both concepts.

(2) A holistic view of BMI envisioning approaches to support different stages of the process (Foss and Saebi, 2017).

(3) A better understanding of how to use the approaches in research/practice (Foss and Saebi, 2017; Geissdoerfer et al., 2018b, 2017b; Nußholz, 2017).

(4) An outline of improvements and opportunities for future research in BMI within CE/sustainability. The paper is structured in six sections. Section 2 introduces foundations of conventional, sustainabilityoriented, and CE-oriented BMI. Section 3 presents the research methodology. The remaining sections present the results including descriptive and comparative analyses of approaches (4), provide a discussion and an agenda to address future research needs (5), and conclude with recapping the research contributions and limitations (6).

\section{Background}

\subsection{Business model innovation (BMI)}

The BM construct emerged in the 1970's and was originally associated with system modelling in information technology. Since the 1990's, the concept has been maturing, with contributions from many disciplines, including technology, organizational and strategy theories (Wirtz et al., 2016). In its modern interpretation, BM is understood as the "design or architecture of the value creation, delivery, and capture mechanisms" of a business (Teece, 2010). In other words, it explains how a business work (Magretta, 2002).

Due to its elusive nature and the comprehensiveness of its scope in the modern interpretations, linking two 'conflicting' domains of knowledge (the technical/physical, generally based on hard facts, and the economic, generally based in uncertain assumptions), the BM construct definition is yet imprecise and has been interpreted in different ways (Gassmann et al., 2016). In general, BM frameworks converge around the notion of a value generation logic of a reference system (e.g. organization, value chain, industry sector), which can be represented by different elements (Wirtz et al., 2016). One of the most referenced representations, the BM Canvas, considers nine building blocks for value generation, organized in four pillars: 'product/value proposition', 'financial aspects', 'customer interface' and 'infrastructure management' (Osterwalder et al., 2005). These four pillars are further refined by Richardson (2008) in three main forms of managing value: 'value proposition', 'value creation and delivery' and 'value capture'. Such representations are related to the static view of BM. 
In parallel to these studies, there is the notion of BM innovation, which consists of changing (by creating, diversifying, acquiring or transforming) $\mathrm{BM}$ as a response to internal and external incentives (Foss and Saebi, 2017; Geissdoerfer et al., 2018b). In this view, BM can be an (1) enabler of strategic changes in innovation processes (e.g. products/services), or (2) the source of competitive advantage acting as innovation itself (Boons et al., 2013).

The dynamic process of BMI can occur in different intensities, related to the degree of novelty introduced (i.e. 'new to the firm' or 'new to the industry') or the scope of changes (i.e. individual components or systemic/architectural structure) (Foss and Saebi, 2017). Moreover, different triggers (internal or external), such as changes in the competitive environment or legislations, can stimulate BM changes.

Recently, BMI is receiving increasing attention in specific areas (e.g. sustainability, CE, servitization, digitization). Due to the importance of these concepts in their individual investigation fields, different 'substreams' emerged (Foss and Saebi, 2017). This article explores two of these 'sub-streams', addressing BMI in the context of sustainability and CE.

\subsection{Sustainability-oriented BMI}

The sustainability-oriented BMI sub-stream has evolved significantly over the past decade, on the basis of seminal works framing the concept (Birkin et al., 2009; Lüdeke-Freund, 2010; Stubbs and Cocklin, 2008); special issues (Boons et al., 2013; Dentchev et al., 2018; Schaltegger et al., 2016a); and reviews of conceptual foundations (Bocken et al., 2014; Boons and Lüdeke-Freund, 2013; Evans et al., 2017b; Geissdoerfer et al., 2018b; Lüdeke-Freund and Dembek, 2017; Schaltegger et al., 2016b; Wells, 2016).

Sustainability-oriented BMI incorporates sustainability principles as guidelines for BM design, adding complexity to the conventional ('business as usual') BMI process. On top of generating superior customer value to achieve competitive advantage and capture economic value, it also seeks to contribute positively to the environment and society. (Lüdeke-Freund, 2010; Stubbs and Cocklin, 2008).

The extent at which sustainability principles will be embedded on the BMs and generate impactful outcomes from a triple bottom line perspective will depend on the levels of ambition of decision makers. Schaltegger et al. (2012)'s typology suggests three strategies for embedding sustainability into BMI: defensive (focus on reducing risks/costs to maintain business as usual), accommodative (focus on ameliorating the BM to reduce impacts) and proactive (focus on completely new designs of the value logic). Proactive strategies usually are more impactful, because they embed sustainability principles in the core logic of businesses, 'rethinking' the value proposition, delivery/creation, and capture systems to maximize societal and environmental benefits, and not only economic profit (Bocken et al., 2014; Wells, 2016).

By addressing value generation logic of businesses for multiple stakeholders beyond the customers, BMI for sustainability intensifies the need for different and more systemic boundaries of analysis. Boons and Lüdeke-Freund (2013) propose three levels of analysis:

(1) Organizational: focused on individual firms and its own value adding activities;

(2) Inter-organizational: focused on the interrelationship with other actors that co-create and share values;

(3) Societal: focused on the interrelationship with other organizations to produce a shared societal value.

To cope with the aforementioned complexity added on top of the conventional BMI, specific methodological support for guiding sustainability-oriented BMI have been proposed in literature. Initial manifestations towards comparing different methodological support exist (Breuer et al., 2018; Schoormann et al., 2016; Schoormann and Knackstedt, 2018), but holistic approaches for sustainability-oriented BMI (i.e. from design to implementation) are still in development stage (Geissdoerfer et al., 2017b). 
Definitions for 'Sustainable BM' have been proposed, but views still require alignment. After reviewing literature for definitions, Geissdoerfer et al. (2018b) define it broadly as BMs "that incorporate pro-active multi-stakeholder management, the creation of monetary and non-monetary value for a broad range of stakeholders, and hold a long-term perspective". Wells (2016) is more precise in emphasizing the concept of 'sufficiency' and social relevance, as he argues that a 'SBM' is "both sufficiently profitable and that results in a process of comparative absolute or relative reductions in environmental and socioeconomic burdens through the delivery of socially relevant products and services". The "sustainable business model (SBM)', 'sustainable business model innovation (SBMI)', 'circular business model (CBM)' and 'circular business model innovation (CBMI)' terminologies have been frequently employed, but we understand that there is no such a thing as an absolute SBM or CBM. Instead, principles/practices that enable a fit with the vision of sustainable development or $\mathrm{CE}$ can be incorporated in BMs. Using the aforementioned acronyms might mislead understandings and hinder the practical implementation of the concepts. Therefore we recall the views of some previous works (Boons and Lüdeke-Freund, 2013; BSI, 2017; Schaltegger et al., 2016a) and address the concepts in this paper either as 'BMI for sustainability or CE' or 'sustainability-oriented and CE-oriented BMI'.

\subsection{CE-oriented BMI}

Research on CE-oriented BMI is even more recent than sustainability-oriented BMI, but has grown rapidly in the last five years (Diaz Lopez et al., 2019). So far, the literature has evolved with seminal works discussing the relevance of the topic (Linder and Williander, 2017) or framing the concept (Lewandowski, 2016; Nußholz, 2017).

As a response to an increasing pressure on our natural resources, $\mathrm{CE}$ aims to create multiple types of values with the ultimate goal of achieving a more resource effective and efficient economic system (EMF, 2015). CE-oriented BMI incorporates principles or practices from CE as guidelines for BM design. It aims at boosting resource efficiency and effectiveness (by narrowing or slowing energy and resource loops) and ultimately closing energy and resource flows by changing the way economic value and the interpretation of products are approached (Bocken et al., 2016; Den Hollander and Bakker, 2016).

The incorporation of circular principles into BMs also occurs at different levels, depending on decision makers' ambitions and adopted strategies. Urbinati et al. (2017)'s taxonomy suggests three available modes of integrating CE principles in BMs: downstream circular (altering value capture and delivery, through new revenue schemes and customer interface - e.g. pay-per-use models), upstream circular (changing value creation systems, e.g. reverse logistics), or fully circular (combining upstream and downstream principles). Similarly to the sustainability proactive strategies, the 'fully circular' business strategies are more impactful for the equilibrium of environmental and economic benefits.

CE-oriented BMI also adds uncertainties and complexity to conventional BMI. New variables have to be considered, for instance, reverse on top of forward logistics; quality, quantity and timing of returns of resources; customers perceptions and preferences for 'as new' (Bocken et al., 2018). This requires a systemic and transdisciplinary view (Sakao and Brambila-Macias, 2018), which has been reflected in recent publications exploring the interfaces of CE-oriented BMI with other innovation perspectives, such as product design, value chain and digital technologies (Bocken et al., 2016; Geissdoerfer et al., 2018a). Methodological support for guiding CE-oriented BMI is already available, including a CE standard (BSI, 2017). However, no systematization of the methodological support developed so far has been proposed. Also, although CE has been recognized as a driver for sustainability, explicit relation of sustainability with CE-oriented BMI is missing. 


\section{Research Methodology}

The main objective of this paper is to systematize the state-of-the-art of available approaches supporting circular-oriented or sustainability-oriented BMI process. These approaches comprise (Osterwalder et al., 2005; Pigosso et al., 2011):

(1) Conceptual frameworks: theoretical approaches promoting common understanding or conceptual alignment about BMI - e.g. diagrams, requirements, typologies, morphologies, taxonomies, ontologies;

(2) Methods: procedures guiding on how to perform BMI - e.g. process model, guidelines.

(3) Tools: instruments supporting the execution of determined BMI activities - e.g. canvas, software.

Based on the overall objective, three research questions were formulated:

R1 - What are the existing approaches for BMI in the context of sustainability and CE?

R2 - Which stages of the BMI process do they support?

R3 - How do they compare to each other?

A systematic literature review was conducted to tackle the overall objective and answer the aforementioned questions. The review protocol (see supplementary information) was organized in three activities: data collection, analysis and reporting (de Almeida Biolchini et al., 2007).

\subsection{Data collection}

Data collection comprised search and selection of existing sustainability-oriented and CE-oriented BMI approaches. The search, in Scopus and Web of Science (July 2018) (Table 1), resulted in 1078 unique publications. In total, 56 publications were selected according to three criteria:

(1) BMI oriented to sustainability or CE explicitly addressed;

(2) Information about the approaches (including foundations and logic) presented;

(3) Generic and holistic approaches proposed (i.e. not addressing specific sectors/individual strategies of CE, e.g. upgrade).

Due to the recent establishment of $\mathrm{CE}$ and to capture the content being generated by practitioners, two additional techniques were applied in a second iteration. A backward snowballing approach (Wohlin, 2014) was performed to capture the established and previous conceptual works (through cross-reference) falling outside of the database searches. The references of the initial selected articles from the academic databases were screened and publications were selected according to their relevance (based on their title, venue of publication or authors' background) for sustainability-oriented and CE-oriented BMI. Subsequently, gray literature was investigated (Adams et al., 2017; Tranfield et al., 2003) and influential non-peer-reviewed publications from non-profits organizations or knowledge platforms on sustainability and CE were included (Table 1). The retrieved publications from snowballing or gray literature searches were subjected to the same screening process (filters and criteria) applied for the academic databases (Fig. 1). The literature review resulted in 94 publications (Fig. 1) selected for analysis (see supplementary information). 


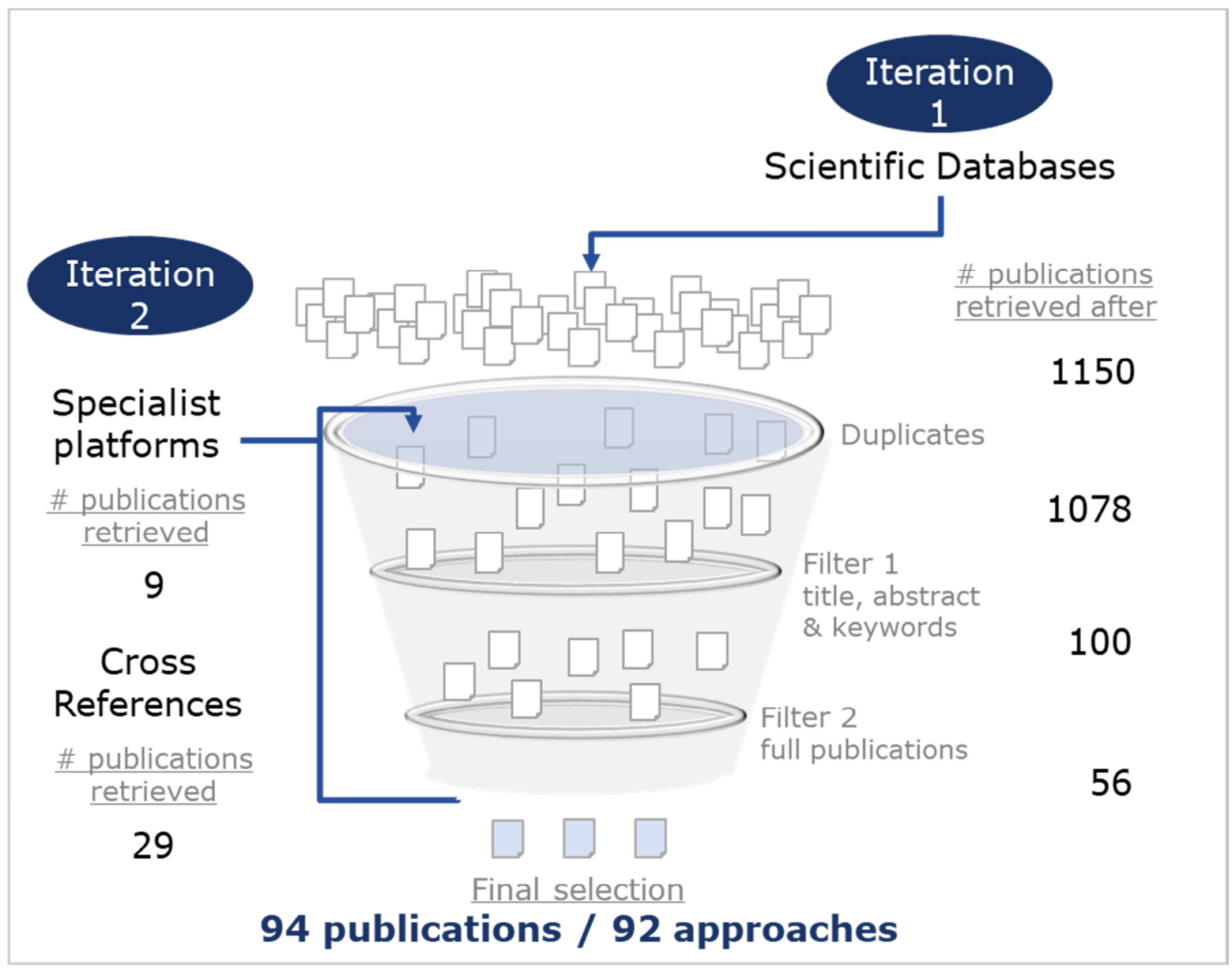

Fig. 1. Systematic literature review process and results.

Table 1. Search parameters $(\mathrm{n} / \mathrm{a}=$ not applicable $)$.

\begin{tabular}{|c|c|c|c|}
\hline Database & Web of Science & $\begin{array}{l}\text { Ellen MacArthur } \\
\text { Foundation(EMF) }\end{array}$ & $\begin{array}{l}\text { CE Practitioner } \\
\text { Guide }\end{array}$ \\
\hline Fields & $\begin{array}{l}\text { (1) title, keywords } \\
\text { (2) title, keywords, abstracts }\end{array}$ & $\mathrm{n} / \mathrm{a}$ & $\mathrm{n} / \mathrm{a}$ \\
\hline \multirow[t]{2}{*}{ Search string } & $\begin{array}{l}\text { (1) ("circular economy"OR"circle economy"ORcircularityORcircle } \\
\text { ORcircularOR"closed loops"OR"sustainable"ORsustainab*)AND } \\
\text { "business models"AND(methodORtoolORframeworkORapproach } \\
\text { ORmethodologyORprocedureORtechniqueORcanvas) }\end{array}$ & business models & $\begin{array}{l}\text { business } \\
\text { models }\end{array}$ \\
\hline & $\begin{array}{l}\text { (2) ("circular economy" OR"circle economy"ORcircularityOR } \\
\text { circleORcircularOR"closed loops")AND"business models"AND } \\
\text { (methodORtoolORframeworkORapproachORmethodologyOR } \\
\text { procedureORtechniqueORcanvas) }\end{array}$ & & \\
\hline Databases filters & English & $\mathrm{n} / \mathrm{a}$ & $\begin{array}{l}\text { resource and } \\
\text { tool }\end{array}$ \\
\hline $\begin{array}{l}\text { Type of } \\
\text { retrieved } \\
\text { publications }\end{array}$ & articles, book chapters, conference papers, reviews & \multicolumn{2}{|c|}{$\begin{array}{l}\text { articles, book chapters, conference } \\
\text { papers, thesis, toolkits, manuals, } \\
\text { online tools, reports, white papers }\end{array}$} \\
\hline
\end{tabular}




\subsection{Data analysis}

From the set of 94 publications, 92 approaches were identified (Research Question 1) and organized according to a three-stages BMI process (Research Question 2) (section 4.2.1) following a dynamic capabilities-based view adapted from Teece (2007):

(1) Sensing: identifying opportunities and generating new BM ideas;

(2) Seizing: systematically designing and testing new BM concepts or configurations;

(3) Transforming: building new competences and implementing organizational renewal.

Teece (2007) proposed this multidisciplinary model to explain how organizations should be prepared to continuously adapt and develop innovations, including BMs. Beyond suggesting processes and tools to support the BMI management, the model opens space for normative or change management aspects (e.g. values, mindset, behaviors, engagement, leadership), shedding light on how human-behavior (represented by managers or decision makers) plays a role in BMI. In our view, this model represents more adequately the 'real world' phenomena, especially in transformational contexts such as sustainability and CE (Roome and Louche, 2016).

Furthermore, a framework was developed to enable comparison by describing other five characteristics of the approaches (Research Question 3): (a) nature of data (section 4.2.1); (b) BMI characteristics (boundaries of analysis, level of abstraction, and time-related view) (section 4.2.2) and (c) representation style (section 4.2.3). The framework was developed in an iterative process by applying content analysis and coding techniques (Dresch et al., 2015). Initial characteristics were developed upfront $(\mathrm{a} / \mathrm{b})$ based on a preliminary literature review. Additional characteristics were added throughout the analysis (c).

\section{Results}

\subsection{Descriptive findings}

Around 34\% of the 94 publications (from 2007 to June/2018) are published in the Journal of Cleaner Production (JCLP). The majority is from Europe (85\%), with the United Kingdom (26\%) leading, followed by the Netherlands $(21 \%)$, Germany $(11 \%)$, Sweden $(7 \%)$ and Finland $(7 \%)$. The development of CEoriented BMI approaches lags behind the sustainability-oriented, with the first publication on CE-oriented BMI appearing in 2013, which coincides with a larger effort with dissemination of CE by institutions such as the EMF (EMF, 2012) and the World Economic Forum (WEF, 2014).

Publications show a rising trend after 2015 (Fig. 2, Fig.3). From the perspective of sustainability-oriented BMI, this might be associated to two special issues focused on BM for sustainability by the journals "Organization and Environment" (Schaltegger et al., 2016a) and JCLP (Dentchev et al., 2018). Likewise, a peak of publications in 2013 coincide with a previous special issue by JCLP (Boons et al., 2013). From the perspective of CE-oriented BMI, the rising trend might be associated to several research projects being funded especially in the European Union since 2014 (European Comission, 2016). Moreover, publications on CE in 2016 have pointed to the lack of appropriate methods and tools for BMI (Bocken et al., 2016; Ghisellini et al., 2016; Lewandowski, 2016), which might have triggered new research lines and contributed to the increasing number of publications in 2017/2018. Still regarding CE-oriented BMI, before 2016 the number of gray literature was larger than the ones retrieved in scientific databases. This is natural considering the very recent dissemination of the concept as a research topic and also due to its appeal to industries and practitioners in general.

The majority of the approaches are either theoretical (45\%) or experimental (50\%) (Fig. 4). From one perspective, this confirms the necessity of advancing research in these sub-streams and supports studies such as this one that can help shedding light on the critical aspects at this stage and ways forward, but 
requires parsimony in the interpretations, since the discourse and conceptual foundations might yet suffer modifications. The complete list of 92 approaches is in the Appendix.

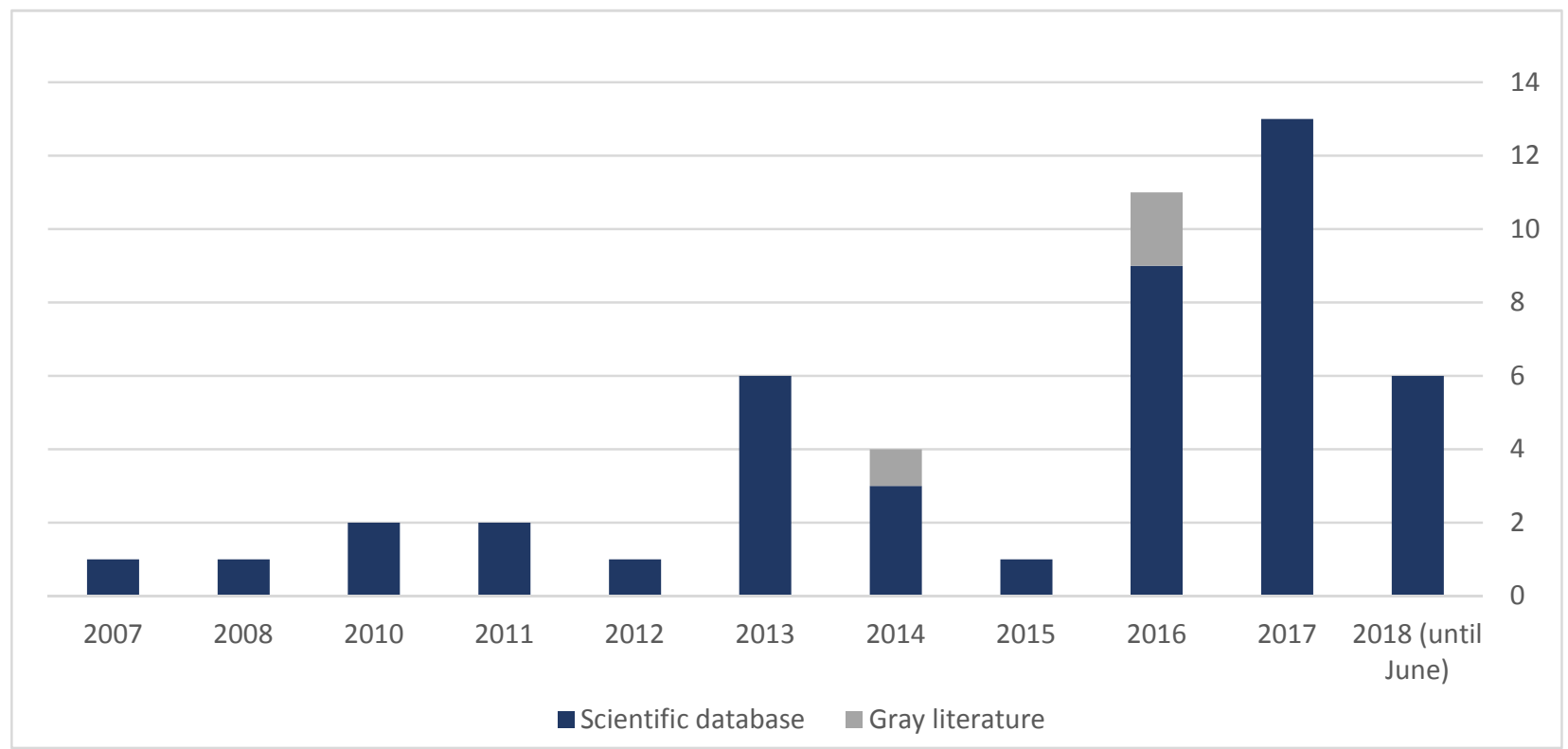

Fig. 2. Publications on approaches for sustainability-oriented BMI.

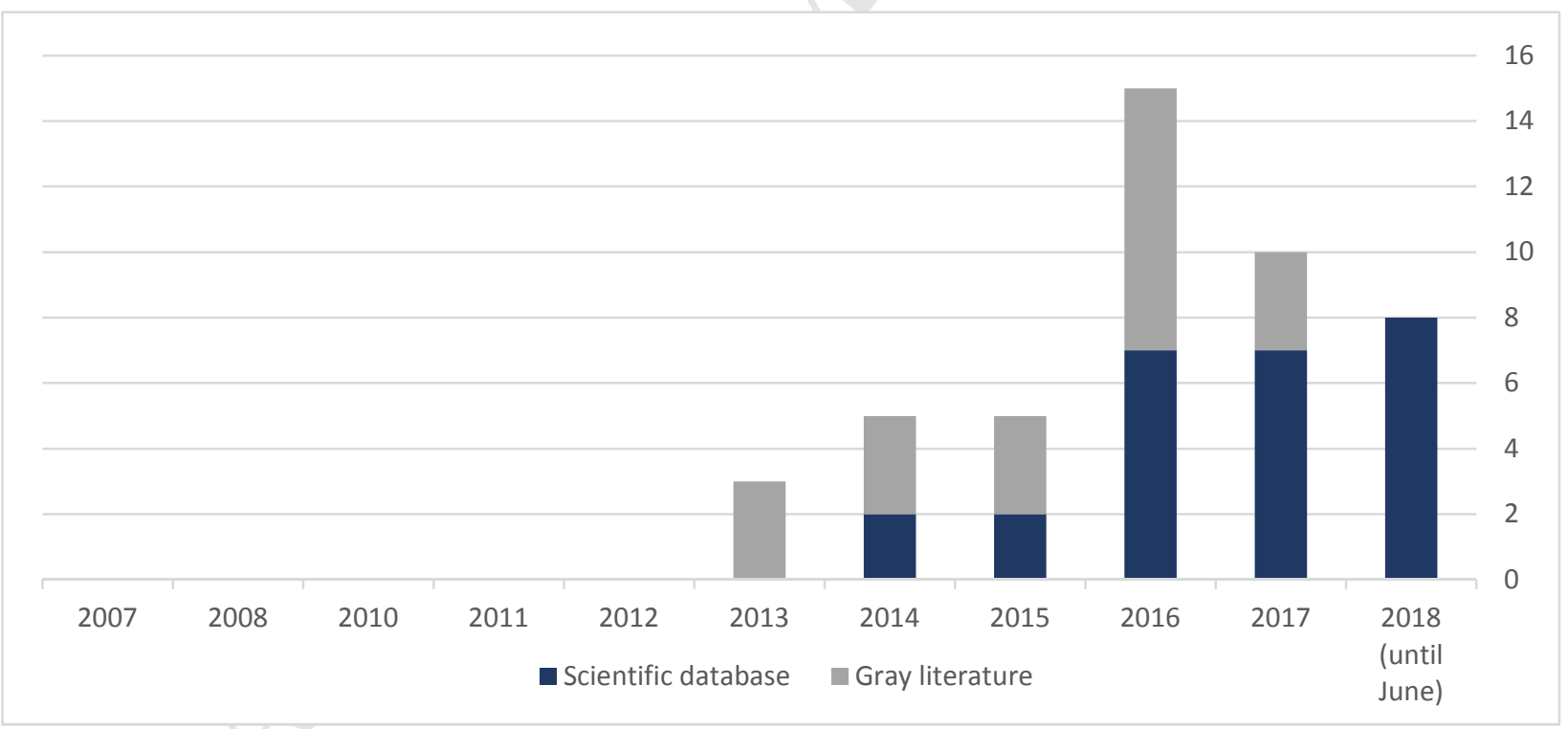

Fig. 3. Publications on approaches for CE-oriented BMI. 


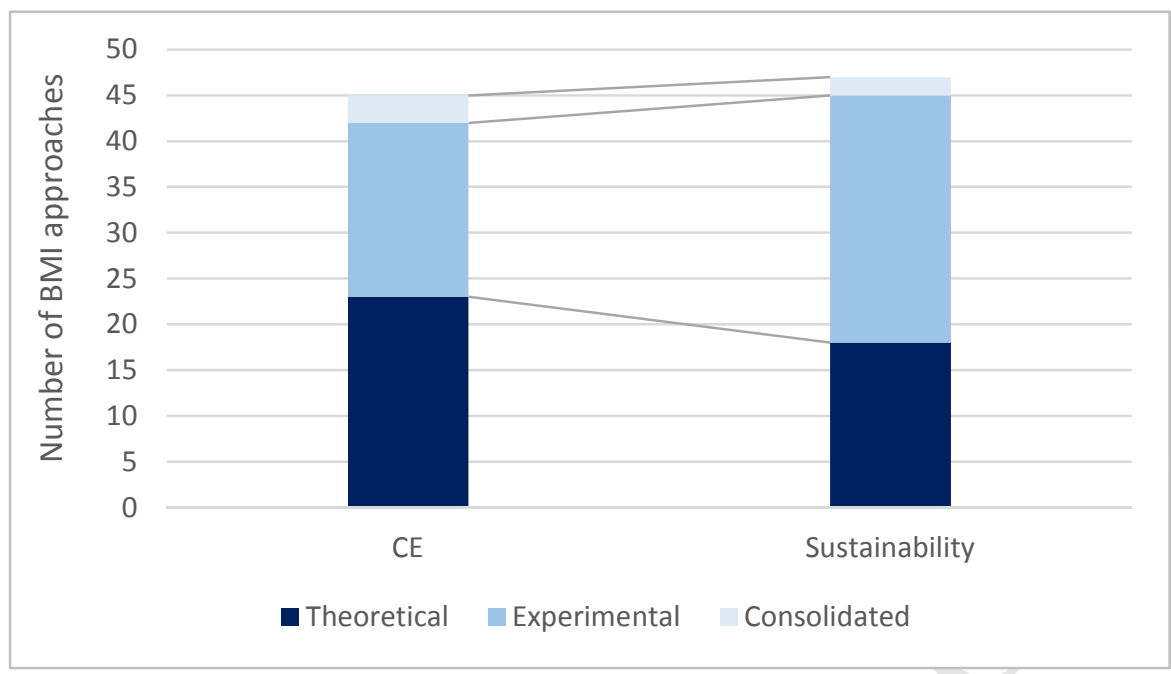

Fig. 4. Development level of approaches for sustainability-oriented and CE-oriented BMI. Legend - Theoretical: conceptual studies; Experimental: case studies/pilot projects; Consolidated: applied regularly in companies.

\subsection{Systematic comparison of approaches}

Our objective with this comparison is to provide an overview and systematize the state-of-the-art in sustainability-oriented and CE-oriented BMI approaches. We structured it in three blocks.

The first block (section 4.3) aims to explore the systemic view of approaches 'composing' the BMI process based on the dynamic capabilities model. In relation to the research questions (section 3), it aims to answer what are the available approaches in practice and literature and how they support the BMI process.

The second and third blocks (sections 4.4 and 4.5) aim to explore the characteristics of single approaches. In relation to research questions (section 3), they aim to answer how the approaches compare to each other.

\subsubsection{Stages of application and data nature}

The distribution of approaches along the BMI process stages are presented in Fig. 5. 80\% of the identified approaches support activities related to sensing (understanding opportunities) and seizing (translating opportunities in BM concepts). Only $20 \%$ of the identified approaches address the transforming stage, which envisions activities of piloting, preparing the organizational capabilities for change, and implementing the new BM concepts. Although success cases of BMs for sustainability or CE appear in literature (Diaz Lopez et al., 2019) and practice (CircleLab, 2018; EMF, 2018), systematized support with methods/tools that can help the dissemination of more successful implementations are still lacking.

Although the majority of approaches address individual activities of a specific stage, there are some approaches covering the complete BMI process (further discussion in section 4.2.3). Five approaches fall outside of the classification as they are related to conceptual foundations of sustainability-oriented or CEoriented BMI, transcending the idea of stages [AR48;AR56;AR60;AR86;AR88] (Evans et al., 2017a; Geissdoerfer et al., 2018a; Laasch, 2018; Randles and Laasch, 2016; Schaltegger et al., 2016b).

The majority of approaches (93\%) use qualitative data for maneuvering decision-making. CE-oriented BMI tend to combine qualitative and quantitative information. This might be related to a pragmatic $\mathrm{CE}$ discourse, oriented to benefit the economic actors of the system and sponsored by practitioners (e.g. businesses, consultancies, government, NGOs) (Geissdoerfer et al., 2017a). It might also explain why 
approaches originated in gray literature appear more frequently in CE (check '*' marks on Fig. 5). Examples of methods for quantitative assessments mentioned by these hybrid approaches are business case (with economic indicators such as return on investment, income, net present value, financial and resources savings, margins and splits to suppliers), life cycle assessment, eco-costs, and multi-criteria decision analysis. Although the focus is larger on assessing economic and environmental aspects, Chiu et al. (2015) [AR28] propose a multi-criteria decision analysis for the selection of BM concepts based on product/service system (PSS) envisioning social aspects such as 'interaction among stakeholders', 'diversity' and 'employment opportunities'. The majority of these hybrid approaches, though, are prescriptive in nature, which means that they provide directions for 'what' is required to be performed, but not necessarily guidance on 'how' to do it. Chiu et al. (2015) [AR28] and Scheepens et al. (2016) [AR39] act on that aspect by proposing tools to support the calculations. Asif et al. (2016) and Lieder et al. (2017) also propose a quantitative simulation tool based on System Dynamics and Agent Based modelling for assessing economic and environmental performance of different BMs for resource efficiency. Due to the requirement of detailed information, the authors recommend the application in advanced stages of validation or implementation of BM concepts.

Finally, as shown in the middle part of Fig.5, some approaches explicitly explore synergies of BMI for sustainability and CE. They combine concepts of sufficiency and eco-efficiency with effective solutions (i.e. closed loops) [AR38;AR53] (Bocken and Short, 2016; Scheepens et al., 2016); propose graphical frameworks to represent the BM concepts with elements of sustainability and CE [AR45;AR81] (Bocken et al., 2018; Kraaijenhagen et al., 2016); or suggest assessment approaches to verify the sustainability potential of CE-oriented BMs (as they highlight that circularity might not necessarily lead to enhanced sustainability) [AR37;AR92] (Antikainen and Valkokari, 2016; de Pádua Pieroni et al., 2018). 


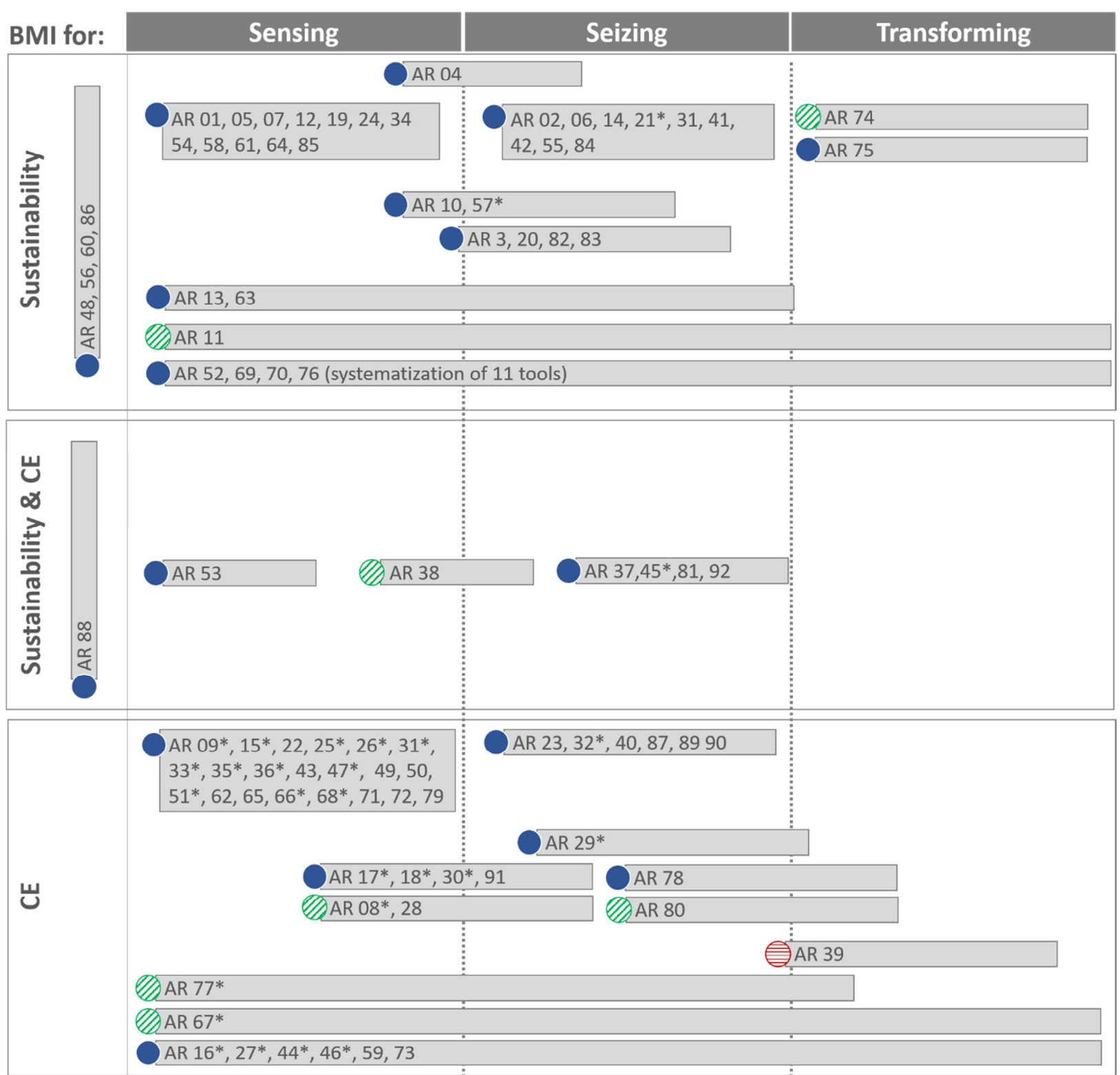

Data nature: Qualitative Quantitative Both

Publication type: * Gray literature

Fig. 5. Stages of application and data nature of sustainability-oriented and circular economy (CE)-oriented BMI approaches [AR] (codes at Appendix). Legend for data nature - Qualitative: support subjective analysis providing general guidance; Quantitative: support objective analysis providing quantification; Both: quantitative and qualitative characteristics. Adapted from Inigo et al. (2017) and Teece (2007).

4.2.2. BMI characteristics: boundaries of analysis, abstraction level and time-related view

This section explores the boundaries set by the approaches to analyze the systemic value flows, their level of accuracy, and their view in respect to BM changes over time (Fig. 6; Table 2).

Concerning boundaries of analysis, despite the importance of inter-organizational collaboration for CE and sustainability, $68 \%$ of the identified approaches still adopt organizational boundaries. That might be a consequence of their foundations, usually building on approaches from the conventional BM literature that 
lay more emphasis on value exchanges through the customer interface (i.e. downstream) than on the value creation (i.e. upstream flows) (e.g. BM Canvas (Osterwalder and Pigneur, 2010)). This could also be related to the fact that, in practice, a lot of complexity is added when BMs are explored at the level of interorganizational boundaries, especially regarding the 'normative organizational aspects' that require new mindset towards alignment of values and establishment of trust among organizations. Only two approaches [AR02;AR86] (Laasch, 2018; Stubbs and Cocklin, 2008) allow for spanning the boundaries of analysis for BMs to a societal level. This is consistent with previous findings in literature of sustainability-oriented BMI (Boons and Lüdeke-Freund, 2013).

Concerning abstraction level, sustainability-oriented BMI approaches are harmonically distributed into the three categories with the moderately aggregated group slightly on the lead (39\%). The largest concentration of CE-oriented BMI approaches is at highly aggregated abstraction level (45\%), which envisions concise representations resembling a 'vision' of the BM concept (e.g. narratives or archetypes). This might be a consequence of CE discourse and dissemination outside of academia, which requires simple, concise and 'catchy' messages that allow for the cognition of the concepts by a diverse public, not familiar with CE (e.g. different types of organizations, sectors, skills or functional areas within organizations).

Concerning perception of changes over time, the majority of approaches adopt a static view, meaning that they interpret the BM concept as 'picture' at a point in time. Only $40 \%$ of approaches adopt the dynamic view, which triggers the need for continuous activities of sensing, seizing and transforming within organizations and requires the development and instantiation of BMI processes focused on, for example, sustainability and circularity. Therefore, not only tools (able to perform determined activities at a point in time), but also methods (such as process models or guidelines) are required as supporting approaches. This is further explored in section 4.2.3.

Table 2. Key characteristics of approaches: BMI aspects.

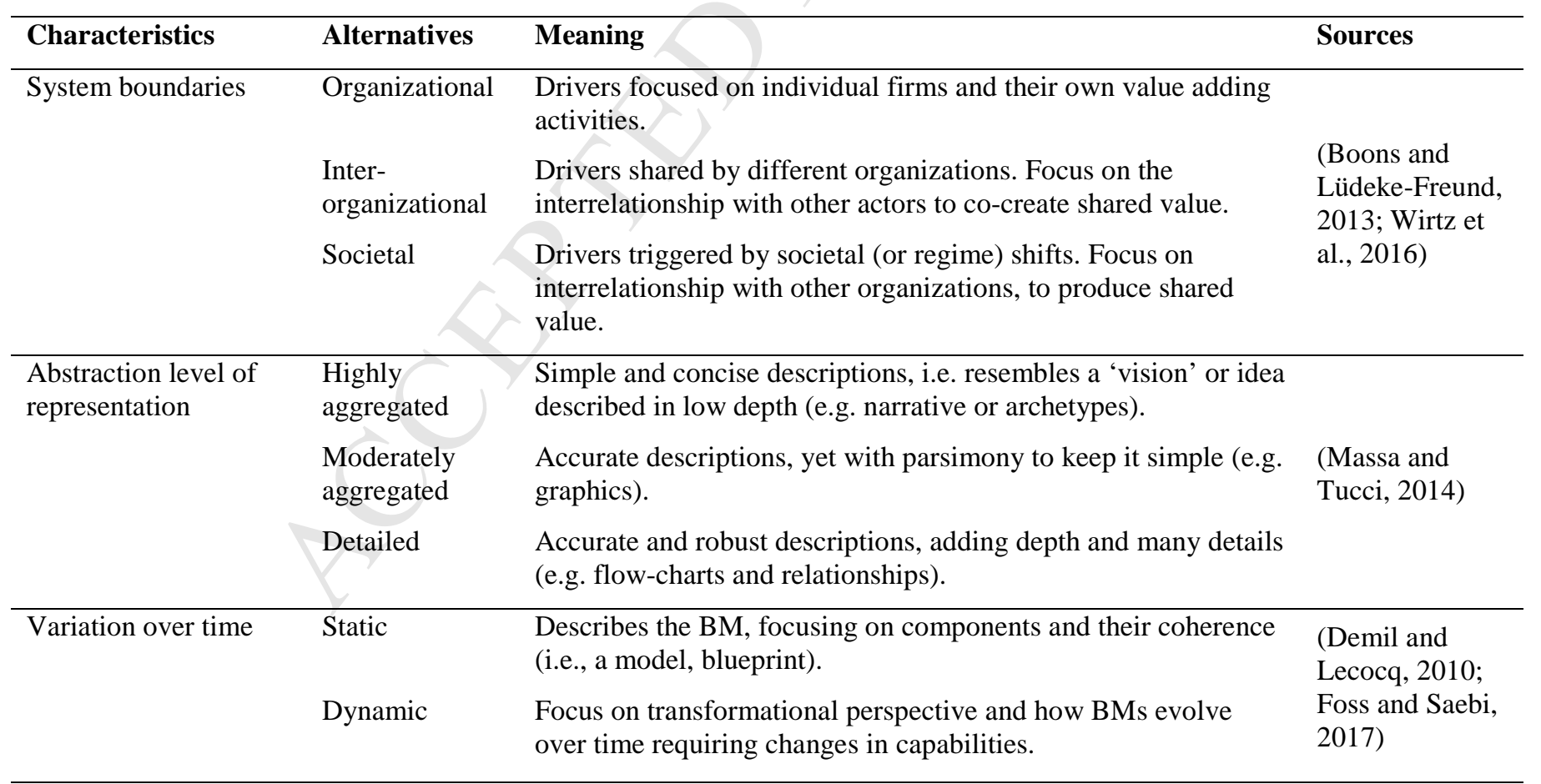




\section{System boundaries}

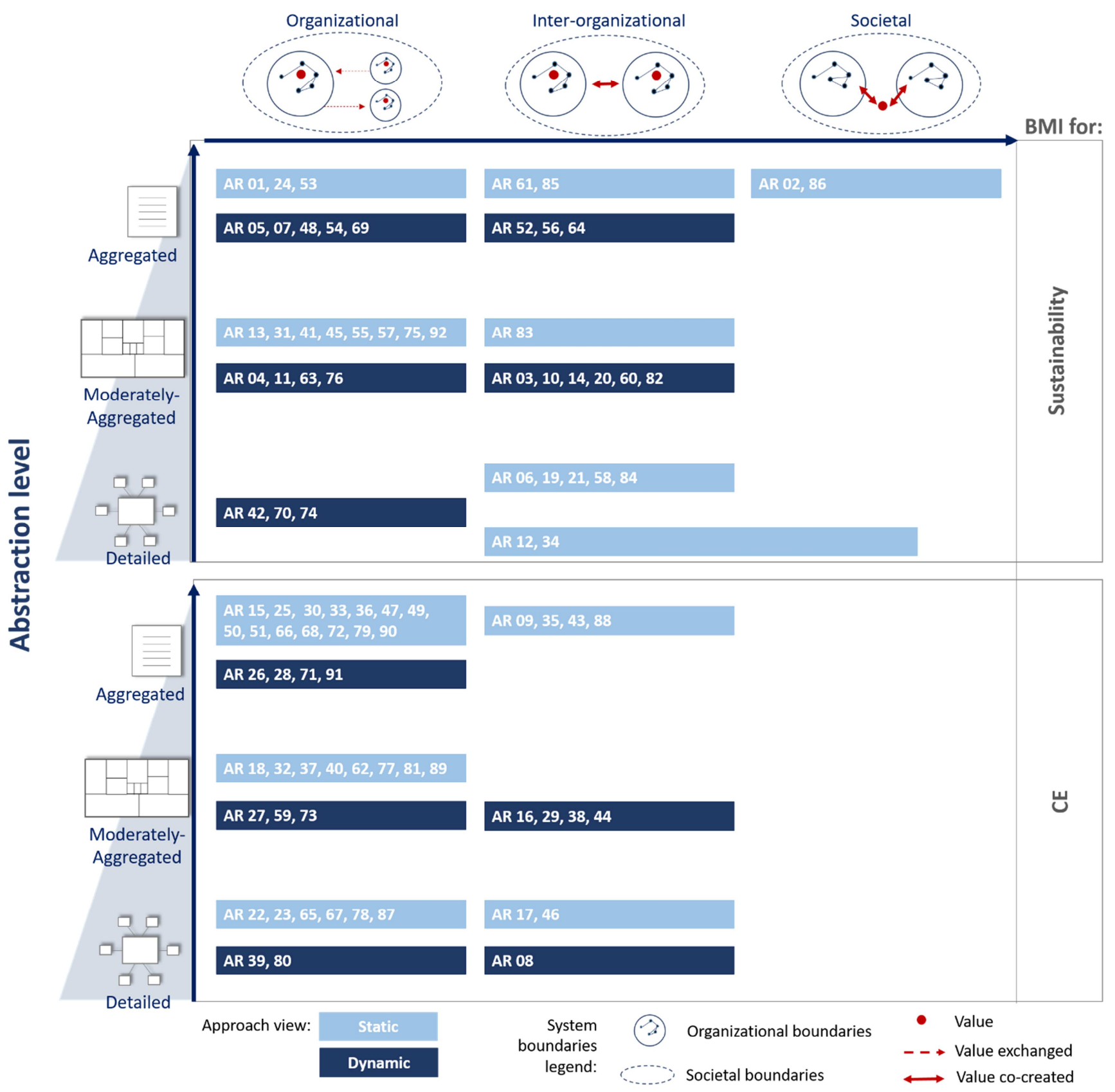

Fig. 6. Abstraction level, system boundaries and time-related view of sustainability-oriented and circular economy (CE)-oriented BMI approaches [AR] (characteristics in Table 2; AR codes in Appendix). Adapted from Massa and Tucci (2014).

\subsubsection{Representation styles}

This section explores different styles of representation considered in the approaches (Fig. 7; Table 3). In terms of conceptual frameworks, typologies and taxonomies are the most common styles of representation both for sustainability-oriented and CE-oriented BMI (44\%). They are used with two purposes to describe: 
(1) paths that organizations follow to transform their BMs from profit-oriented ('conventional') to sustainability/CE-oriented [AR54, AR56] (Jabłoński and Jabłoński, 2016; Schaltegger et al., 2016b);

(2) mechanisms or solutions that contribute to designing sustainability/CE-oriented BMs [AR01, AR15, AR24, AR25, AR27, AR33, AR49, AR51, AR53, AR54, AR56, AR68, AR72, AR79, AR85, AR91].

Bocken et al. (2014) [AR24] is the most cited typology, introducing eight archetypes for sustainabilityoriented BM (maximize material and energy efficiency; create value from 'waste'; substitute with renewables and natural processes; deliver functionality rather than ownership; adopt a stewardship role; encourage sufficiency; re-purpose the business for society/environment; and develop scale-up solutions). CE-oriented BMI comprises variations of typologies (Accenture, 2014; Bakker et al., 2014; Bocken et al., 2016; Bocken and Short, 2016; Diaz Lopez et al., 2019; Forum for the Future, 2016; Lacy et al., 2013; Weetman, 2016; WRAP, 2018). Some authors attempted to systematize them [AR72, AR79] (Nußholz, 2017; Planing, 2018), but due to the recent development of the field, it is still early to identify preferences and signs of consensus towards the adoption of one over the others.

Concerning methods, process models (considered one type of method in our classification) covering the three stages of BMI are the least frequent category of approaches (14\%). The ones available differ considerably in the names for the BMI stages and the content presented, which might include required activities [AR16, AR52, AR70, AR73] (Antikainen et al., 2017; Geissdoerfer et al., 2017b; Mentink, 2014; Roome and Louche, 2016), expected deliverables [AR52, AR73] (Antikainen et al., 2017; Roome and Louche, 2016), applied tools [AR11] (Girotra and Netessine, 2013), challenges and enablers [AR52, AR70] (Geissdoerfer et al., 2017b; Mentink, 2014; Roome and Louche, 2016), or organizational change management tasks [AR44, AR52] (Kraaijenhagen et al., 2016; Roome and Louche, 2016)). They also have varied styles of representation ranging from textual documents [AR13, AR46] (Holgado et al., 2013; Weetman, 2016) to visual representations, such as linear process flows [AR52, AR67, AR70, AR73] (Antikainen et al., 2017; Geissdoerfer et al., 2017b; REBus, 2015; Roome and Louche, 2016), circular process flows [AR16, AR27, AR44, AR59] (Kraaijenhagen et al., 2016; Mendoza et al., 2017; Mentink, 2014; van Renswoude et al., 2015), and innovation-like funnels [AR11, AR63] (França et al., 2017; Girotra and Netessine, 2013).

Concerning tools, the ones focused on visualization of the BM concepts are the most applied. Different types of visualization tools are available, ranging from component based diagrams in canvas format [AR3, AR10, AR18, AR20, AR21, AR28, AR29, AR31, AR32, AR37, AR40, AR41, AR45, AR57, AR63, AR77, AR81, AR89] (Antikainen and Valkokari, 2016; Bocken et al., 2018; Breuer and Lüdeke-Freund, 2014; Chiu et al., 2015; Dewulf, 2010; EMF, 2016; França et al., 2017; Jones and Upward, 2014; Joyce and Paquin, 2016; Kraaijenhagen et al., 2016; Lewandowski, 2016; Mentink, 2014; Nußholz, 2018; Rohrbeck et al., 2013; Sempels, 2013; Sustainn, 2017; Tiemann and Fichter, 2016; Wiithaa, 2018), circular format [AR35] (Materials, 2016), or life cycle format [AR19, AR78, AR89] (Manninen et al., 2018; Nußholz, 2018; Miying Yang et al., 2017); arrow or process diagrams [AR19, AR58, AR63, AR74, AR77] (França et al., 2017; Kurucz et al., 2017; Sustainn, 2017; Yang et al., 2014; Miying Yang et al., 2017); matrices [AR61] (Haanstra et al., 2017); flowcharts or loops [AR17, AR26, AR36, AR84] (Achterberg et al., 2016; Bakker et al., 2014; Brehmer et al., 2018; Mentink, 2014); co-centric geometric forms [AR12, AR38] (Bocken et al., 2013; Scheepens et al., 2016); tables or lists [AR43] (Aminoff et al., 016); and hierarchical representations of circular strategies or of the life cycle [AR36] (Achterberg et al., 2016).

The representation styles are different along the three BMI stages, as they vary in objective and expected deliverables. For instance, the 'seizing' stage is uniformly supported by component-based diagrams tools 
that represent the BM design options for alternative configurations. On the other hand, tools for 'sensing' opportunities are more diverse in shape, as the activity is abstract and creative.

Visualization tools are especially important and recurrent in the 'seizing' stage, where they provide an easy and collaborative way of defining the composition (in terms of elements) of future BMs. The tools are usually variations of conventional BMI tools. For instance, tools for 'seizing' being proposed until 2017 often ended up with variations of the BM Canvas (Osterwalder and Pigneur, 2010). New approaches from 2018 started to build on the Activity Systems perspective (Zott and Amit, 2010), as they defend that it enables a more adequate fit with collaborative requirements of sustainability or $\mathrm{CE}$, with enhanced visualization and consideration of multiple stakeholders beyond the firm-centric view.

Table 3. Key characteristics of approaches: representation styles.

\begin{tabular}{|c|c|c|c|}
\hline Alternatives & & Meaning & Sources \\
\hline \multirow[t]{2}{*}{ Method } & $\begin{array}{l}\text { Guideline/ } \\
\text { manual }\end{array}$ & General guidelines to be followed during the BMI and design. & \multirow{6}{*}{$\begin{array}{l}\text { (Lüdeke- } \\
\text { Freund et } \\
\text { al., 2018; } \\
\text { Osterwalder } \\
\text { et al., 2005; } \\
\text { Pigosso et } \\
\text { al., 2011) }\end{array}$} \\
\hline & Process model & $\begin{array}{l}\text { A set of activities and steps that represents the complete or parts of the } \\
\text { process for BMI. }\end{array}$ & \\
\hline \multirow[t]{4}{*}{ Tool } & Cards & Paper-based tool describing opportunities/design options. & \\
\hline & Serious game & $\begin{array}{l}\text { Paper-based/computational tool that simulates a part or the complete } \\
\text { BMI process. }\end{array}$ & \\
\hline & $\begin{array}{l}\text { Visualization } \\
\text { tool }\end{array}$ & $\begin{array}{l}\text { Paper-based/computational tool using visual techniques to represent the } \\
\text { logic of value generation/flow within one/multiple organizations. }\end{array}$ & \\
\hline & $\begin{array}{l}\text { Simulator/ } \\
\text { Software }\end{array}$ & $\begin{array}{l}\text { Computational tool supporting the application of BM tools (might } \\
\text { include concepts of decision making theory). }\end{array}$ & \\
\hline
\end{tabular}




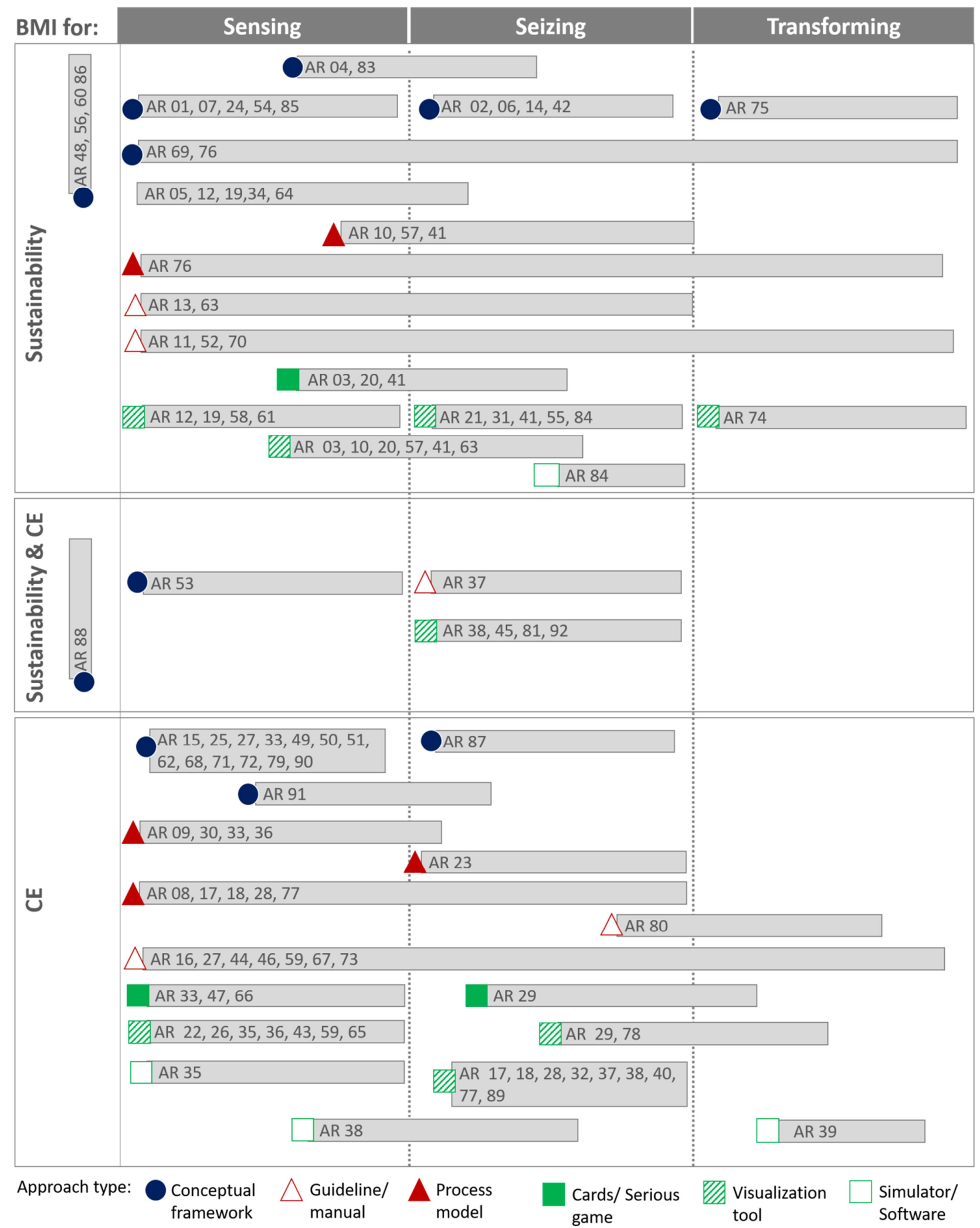

Fig. 7. Styles of representation of sustainability-oriented and circular economy (CE)-oriented BMI approaches [AR] (characteristics in Table 3; AR codes in Appendix). Adapted from Inigo et al. (2017) and Teece (2007). 


\section{Discussion}

This section discusses the key findings of the study with respect to the research questions (section 3), identifying the most important trends in approaches for CE-oriented and sustainability-oriented BMI. Moreover, the main gaps are summarized and translated into a future research agenda.

\subsection{Key research findings}

Although recent, research on approaches for sustainability-oriented and CE-oriented BMI is receiving increasing attention. This research identified, compared and categorized 92 approaches. A key finding is that these proposed approaches usually address individual stages of the BMI without considering the continuous activities necessary to adapt the companies' capabilities to the dynamic changes (internally or externally) required by ' $\mathrm{CE}$ /sustainability thinking'. Many publications do not contextualize the BMI stage in which they are contributing to, as if they assumed that BMI was only about single stages (e.g. designing $\mathrm{BM}$ representations). These results are consistent with recent findings in conventional BMI literature (Wirtz et al., 2016), indicating that these topics are not comprehensively considered by researchers, despite its importance and complexity (Foss and Saebi, 2017). Moreover, it could be contributing to a designimplementation gap in sustainability-oriented BMIs (Ceschin, 2013; Geissdoerfer et al., 2017b).

The analyzed approaches seem to be more advanced in helping companies in identifying opportunities (sensing) and designing new business model concepts for CE or sustainability (seizing). However, there is a lack of methods/tools for experimenting, testing, and implementing the BM concepts (transforming). Bocken et al. (2018) emphasize the importance of experimentation and the on-going 'learning by doing' process for sustainability-oriented/CE-oriented BMI. Similar gaps were identified in the innovation processes for products (Brones and Monteiro de Carvalho, 2015) or services (Lee, 2016; Rosa et al., 2017), and might be due to required skills/knowledge from other fields (e.g. project management, organizational change management) transcending the expertise of innovation/design; or needs for longitudinal research approaches, which have a longer-term nature than design and conceptualization. Without envisioning this last stage, we will not truly understand the effectiveness and impact of BMI approaches to leverage sustainability or CE principles.

A second key finding emerging from the comparison indicates that CE/sustainability-oriented BMI approaches are becoming more heterogeneous and relying on multiple theories that deviate from the traditional view disseminated by the BM Canvas (Osterwalder and Pigneur, 2010). Variations lie in the way approaches adopt boundaries to analyze systemic value flows (organizational, inter-organizational, and societal), the level of accuracy enabled in the BM concepts representation, the view in respect to changes in the BM over time, and mainly, in the types and styles of BM representation. Examples of types of representation include checklist, figure/model, visualization tools, guideline/manual, matrix, morphology/ morphological box, ontology, process model, requirement, serious games, simulator/configurator, software, taxonomy, typology. Each type of approach presents also multiple styles; for instance, visualization tools present more than ten variations (e.g. canvas format, matrices, life-cycle format). There seems to be a correlation of particular representation styles in different BMI stages, as they vary in objective and expected deliverables. Usually the level of details in the BM representation enabled by the approach increases as it gets closer to the transforming stage. Regarding the boundaries set by the approaches to analyze the systemic value flows, there is a trend of approaches moving to an inter-organizational (Biloslavo et al., 2018; Brehmer et al., 2018) or societal levels (Laasch, 2018; Stubbs and Cocklin, 2008), as this aligns better with sustainability/CE principles.

A third key finding regards a limitation of incorporation of human-behavior aspects into the approaches. Randles and Laasch (2016) and Boons and Lüdeke-Freund (2013), discuss the role of normative aspects, 
such as leadership and organizational culture in enabling the transformation towards sustainability-oriented BMI. Kraaijenhagen et al. (2016) incorporate change management activities in their cyclical process for CE-oriented organizational transformation. Our intention with employing Teece (2007)'s dynamic capabilities model as the backbone for the categorization of approaches was exactly to broaden the lens of innovation management to include normative and change management aspects, which in our view represents the real world phenomena with superior fidelity. The framework worked successfully in the categorization and enabled explaining the complex process more concisely than alternative models identified in this study (e.g., Geissdoerfer et al. (2017b); Girotra and Netessine (2013); Mentink (2014)). Moreover, it helped emphasizing the gap in human-behavior orientation in CE/sustainability-oriented BMI approaches, which might be hindering an impactful application of methods/tools. The BMI stages based on a dynamic capabilities view can facilitate the coordination with other innovation processes that focus on different BM elements (e.g. product development, processes innovation) (Mezger, 2014), which is fundamental to guarantee that the sustainable or circular values embedded in a specific BM architecture will be seized after the BM implementation (Pieroni et al., 2018).

Finally, as a fourth key finding, researchers' discourses seem to converge about the notion that CE is 'one way' - and not the only one - towards sustainability, and that CE-oriented BMs are 'a possible archetype' (Bocken et al., 2014) of sustainability-oriented BMs. However, the interface of both concepts is superficially addressed by the approaches, undermining the potential capture of synergies of both research streams, such as for instance, the assessment whether CE BMs are truly contributing to the ultimate target of sustainable development or whether and how approaches can be used interchangeably in both streams. Especially regarding the development of methods/tools, the streams seem to be following 'individual' paths, with few works applying the concepts simultaneously (Antikainen and Valkokari, 2016; Bocken et al., 2018; Bocken and Short, 2016; de Pádua Pieroni et al., 2018; Geissdoerfer et al., 2018a; Kraaijenhagen et al., 2016; Scheepens et al., 2016).

To advance this aspect, we propose a comparative view based on the scope or core drivers for value generation usually adopted by CE/sustainability-oriented BMI approaches (Fig. 8). This aims to suggest an initial reflection to promote future research (complementing the systematic comparison from section 4.2). The comparative view is built upon approaches that explicitly discuss principles for sustainability-oriented or CE-oriented BMI (Bocken et al., 2016; Breuer et al., 2018; Geissdoerfer et al., 2018a; Wells, 2016), and complemented by examples of other approaches' positioning in regards to the CE-oriented vs. sustainability-oriented BMI scope (top lane of Fig.8). Moreover, we provide examples (second/third lanes in Fig. 8) of how BMI archetypes or design options are addressed differently by approaches from each scope. Approaches from sustainability-oriented BMI usually suggest additional BM archetypes (e.g. base of pyramid solution) and BM design options (e.g. participatory approaches) when compared to CE-oriented BMI.

Providing customer superior value is a driver both for CE-oriented and sustainability-oriented BMI, as without this, the value capture in monetary terms might not occur, hindering the longevity of the business (de Pádua Pieroni et al., 2018; Geissdoerfer et al., 2018a; Lüdeke-Freund, 2010). On top of that, the main drivers for CE-oriented BMI are resource efficiency, resource longevity/effectiveness, and economic growth (despite natural resource restrictions) (Geissdoerfer et al., 2017a). CE-oriented BMI might also generate value to social relevance or work enrichment, but those are depicted as secondary effects (dotted arrow in Fig. 8), instead of core drivers for value generation. When this happens, CE-oriented BMI (greenellipse in Fig.8) contributes positively to the wider scope of sustainability (blue ellipse in Fig. 8). However, negative effects might also occur. According to Urbinati et al. (2017), design options for CE might be partially in place in the BMI. For instance, they can foster solely downstream circularity, seeking for customer superior value (e.g. cheaper access to a product by paying-per-use instead of paying-for- 
ownership). Not necessarily, appropriate upstream design options (e.g. 'closed-loop reverse logistics') are in place, hence the drivers of resource efficiency/longevity are not deployed. In that case, BMI might generate negative secondary effects that are unsustainable, such as overconsumption, fast obsolesce/replacement (e.g. pay-per-use cell phone schemes allowing customers to get the latest model every year; generation of toxic material during recycling).

Differently from CE-oriented BMI, sustainability-oriented BMI holds social relevance as a key driver for value generation on top of resource efficiency/longevity and superior customer value. Another difference, is the consideration of trade-offs regarding the economic perspective. This means, business longevity and sufficiency (e.g. in consumption/production) can be prioritized over a rapid profit-maximization strategy in order to perpetuate the positive impacts on social or environmental aspects. To better illustrate the differences, we compare two company-cases: FLOOW2 and Globechain. FLOOW2 is a business-tobusiness marketplace facilitating rental/sales of used equipment, services, and knowledge of personnel. FLOOW2's main value proposition is CE-oriented: to help customers in reducing costs or increasing revenues with better allocation/use of idle assets. However, they promote secondary benefits related to social relevance and work enrichment as a consequence of the 'sharing' configuration, i.e., a new dynamics and culture of collaboration that stimulates connection and toleration (CircleLab, 2018). Globechain is also a platform to facilitate reuse, connecting businesses and charities. Their value proposition is inserted in the scope of sustainability, since they aim to enable global redistribution of goods to social causes rather than disposal. As part of their value proposition, they support donor companies with waste audits and social impact value assessments (CircleLab, 2018).

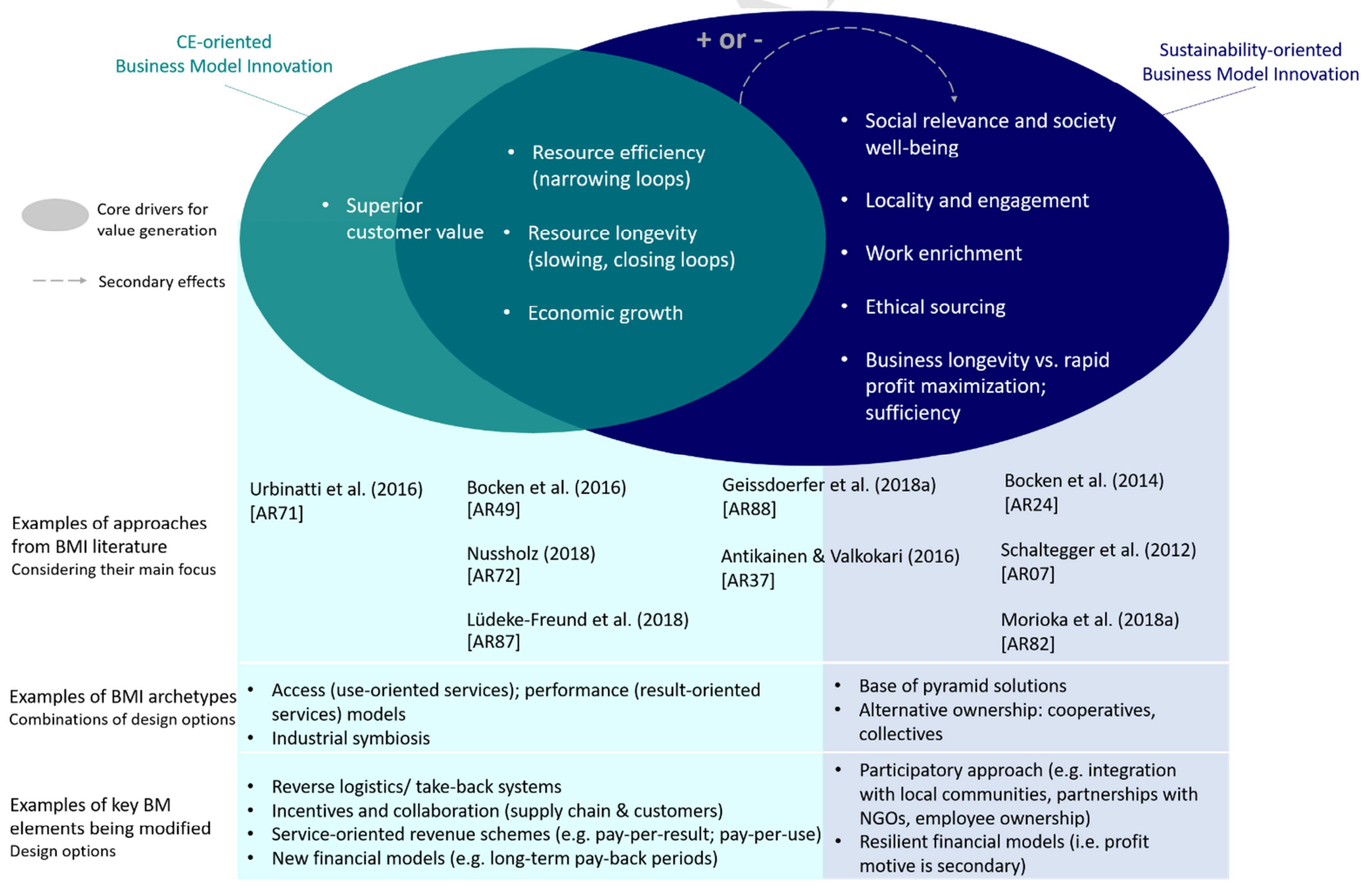

Fig. 8. Comparison of scopes of CE-oriented and sustainability-oriented business model innovation approaches. 
In summary, CE-oriented BMI is not always able to capture the full potential of sustainability. Some CEoriented BM configurations, even when fully circular, might generate negative secondary effects. On the other hand, they might contribute positively to sustainability-oriented BMI principles. Finally, not all CEoriented BMI approaches accommodate sustainable principles and not all sustainability-oriented BMI approaches accommodate circular principles. These considerations reflect academic discussions presented until now. However, CE is in a development trajectory (Blomsma and Brennan, 2017). Considerations of its scope might change, incorporating potentially even more constructs from the wider space of sustainability.

\subsection{Advancing research on sustainability-oriented and CE-oriented BMI}

The systematic comparative analysis of the 92 approaches enabled the identification of gaps either pointed as limitations by the authors or inferred with the support of the characteristics employed for analysis. We translated these gaps into future research needs and structured proposals to advance research on approaches for sustainability/CE-oriented BMI divided in four aspects (Fig. 9):

(1) Establishing consensual foundations and taking advantage of synergies:

- Moving beyond the customer interface: publications diverge in their interpretation of BM and some have a reductionist approach, interpreting BM solely as the commercial or revenue model configurations (downstream value generation logic). Especially for CE, decisions regarding the upstream value logic structure are as important as downstream and fundamental to enable closed-loop configurations in value chains. Future research should work for establishing a consensus and emphasizing that sustainability/CE-oriented goes beyond the customer interface.

- Consolidating types of mechanisms/configurations: the existence of different propositions of archetypes for CE-oriented BMs without a consensus might hinder the knowledge consolidation in the field. Establishing common discourse/language to facilitate the dissemination and adoption of circular objectives collaboratively at an inter-organizational or societal level is fundamental. A recently issued British standard (BS 8001:2017) provides guidance on the possible types of $\mathrm{BM}$ that can be compatible with $\mathrm{CE}$, including considerations for their selection. They present seven BM groupings: (1) on demand, (2) dematerialization, (3) product life cycle extension/reuse, (4) recovery secondary raw materials/by-products, (5) product as a service/product-service systems (PSS), (6) sharing economy/platforms and (7) collaborative consumption. Maybe this could be a first step to starting a convergence of terminology.

- Integration of sustainability and CE-oriented BMI: the simultaneous application of CEoriented and sustainability-oriented BMI approaches is still not fully explored. We have proposed in section 5.1, an initial comparison of BMI scope for both streams in order to initiate a proactive discussion and exploration of synergies. Some BM methods already suggest using sustainability tools into CE contexts. Future research should explore their applicability and appropriate combinations.

(2) Addressing sustainability-oriented and CE-oriented BMI as a continuous/holistic process:

- Holistic view: as indicated in section 5.1, approaches in general could benefit from exploring CE/sustainability BMI with 'process model' lenses. To avoid confusion and contribute to the required longitudinal transformational perspective, where new abstract values and visions need to be disseminated and translated into the operative level, we encourage researchers to contextualize their contributions in regards to the holistic view of 
BMI in light of principles of CE/sustainability. Process models have been proposed (Fig. 7), so authors could either decide to reference the existing ones (i.e. we adopted the three stages 'sensing', 'seizing', 'transforming') or systematize new proposals. No matter how it will occur, it is important to clarify the dynamic nature of BMI to implement principles (i.e. it is a continuous and long journey instead of a single shot initiative).

- Design-implementation gap: in section 5.1, we pointed out the trend of exploring experimentation approaches for sustainability/CE-oriented BMI (Bocken et al., 2018). Beyond this, future research aiming to contribute to decreasing this gap could engage in integrating knowledge from other theories - e.g. strategic and long-range planning (Phaal et al., 2004), entrepreneurship, project/organizational transformation management (Chapman, 2002), and dynamic capabilities (Teece, 2007). This requires new empirically oriented tools and research methods (check groups 3/4).

(3) Adapting existing methods/tools or exploring new ones to fill in specific gaps:

- Inter-organizational and societal boundaries: the majority of methods and tools still adopt organizational boundaries. Future research should explore how to take the interorganizational or societal boundaries into account. Some recent tools already incorporated that by adopting different theories from conventional BMI beyond the BM Canvas. We expect that the adoption of Activity Systems (Zott and Amit, 2010) or other new theories might increase in the future.

- Quantitative methods and tools: another future need is the development of quantitative methods and tools to support decision-making. Such tools could propose indicators and measures to assess different concepts of BM economically, environmentally and socially. Attention should be placed on discussions of what types of indicators and assessments to apply for each stage of BMI as a consequence of different levels of detail and intentions. The quantitative assessment could also serve as bridge for the design-implementation gap (Geissdoerfer et al., 2018b), as a way of establishing concrete targets for business outcomes that should be monitored longitudinally along the BMs implementation.

- Customization of approaches from conventional BMI literature: It might also be the case that new tools are not necessary, but instead, the customization of existing ones. The notion that BMI for sustainability or CE is a process and not only the outcome, implies that a combination of tools might be required and not only one single visualization tool. In that case, it might be worth exploring how tools from conventional BMI, that are already consolidated, could be adapted or supplemented with other tools for sustainable or resource efficiency innovation in order to instigate circular/sustainable thinking.

- Normative and people change management aspects: values (individual, organizational, societal), organizational culture, mindset, effective communication and leadership are important to be in place, in addition to effective tools or methods (Birkin et al., 2009; Lüdeke-Freund et al., 2018; Randles and Laasch, 2016). These aspects are catalyzers for incorporating sustainability principles into BMI (Randles and Laasch, 2016). The embedment of these considerations in the methodological support development shall be further explored.

(4) Applying different research methods:

- Empirical studies: empirical studies based on field research are required to move the composition of approaches from theoretical/experimental stage and contribute to their maturation. 
- Longitudinal studies and action research: the implementation of BM concepts is as important as designing them, as this leads to real transformations in organizations. This should be investigated with practical research methods such as (i) action research, which enables the investigation of the aspects or results of the use of the conceptual frameworks, methods and tools in real-time, instead of only retroactively; and (ii) longitudinal research, which enables the evaluation of the long-term consequences and results of applying the approaches, and consequently their success.

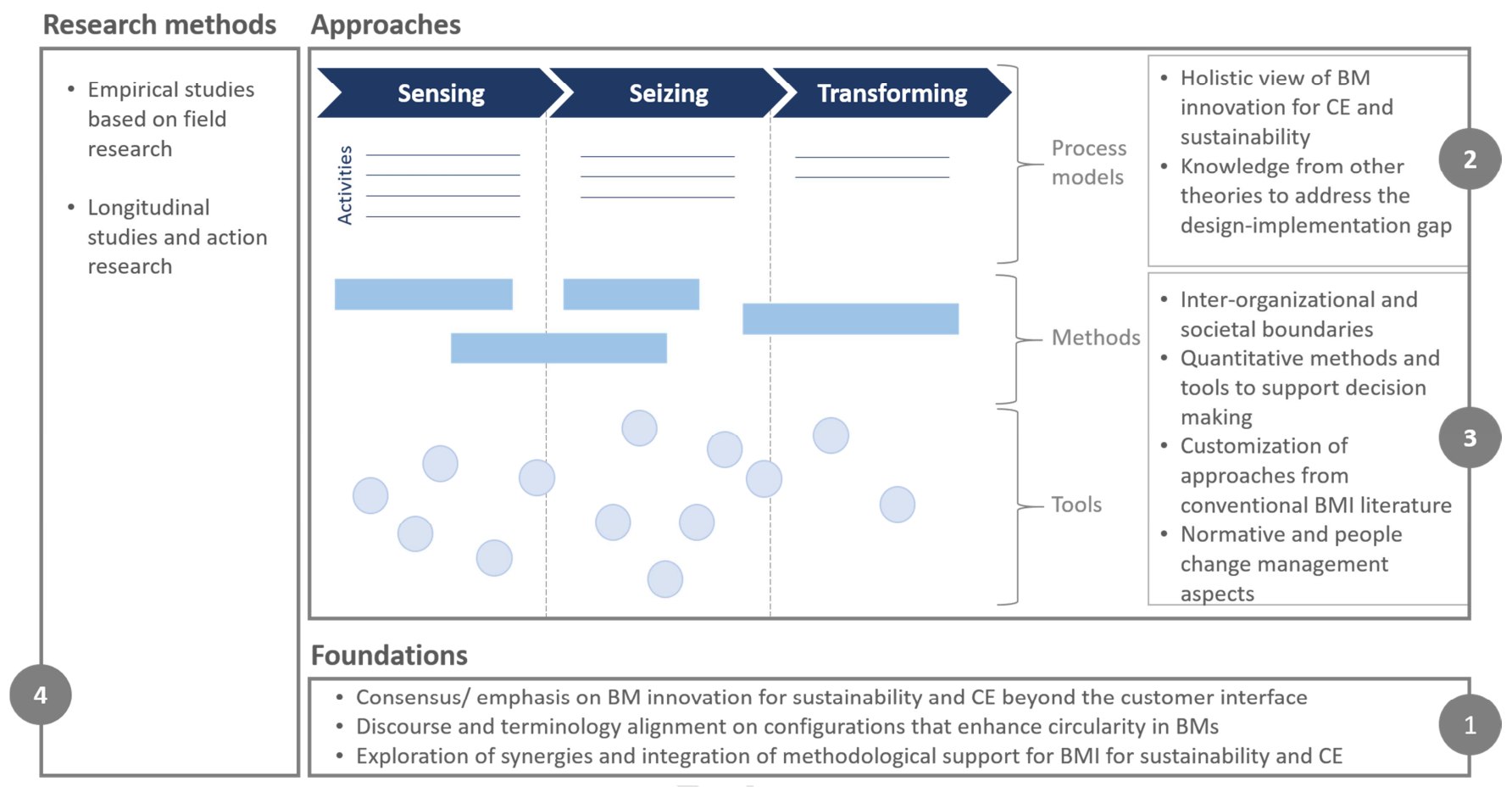

Fig. 9. Research framework and guideline for selection of approaches for sustainability-oriented and circular economy (CE)-oriented business model (BM) innovation.

\section{Conclusion}

This research aimed to identify and systematize CE-oriented and sustainability-oriented BMI approaches available in literature and practice, in order to provide a clear overview on this topic for scholars and practitioners.

Applying a three-stage (sensing, seizing, transforming) dynamic capabilities-based view as the backbone to represent the stages of BMI, this article systematically identified and compared 92 approaches - i.e. conceptual frameworks, methods and tools - for sustainability/CE-oriented BMI based on six characteristics: stages supported in the BMI process; nature of data; boundaries of analysis; level of abstraction; time-based view; and representation style.

Based on the analysis, key findings outlining trends of approaches were identified: approaches are becoming more heterogeneous and relying on multiple theories that deviate from the traditional view disseminated by the BM Canvas; the simultaneity of BMI approaches envisioning sustainability and CE principles is emerging timidly and deserves more exploration to flourish; a design-implementation gap might be associated to approaches focusing on single stages of BMI and also a negligence of humanbehavior aspects. Connected to our first key finding, we proposed an initial comparison for $\mathrm{CE} /$ sustainability-oriented BMI based on their scope or drivers for value generation. Moreover, a number of 
gaps and future research agenda to advance both fields simultaneously were outlined: (1) establishing consensual foundations and taking advantage of synergies, (2) addressing CE/sustainability-oriented BMI as a continuous and holistic process, (3) adapting existing methods/tools or exploring new ones to fill in specific gaps, and (4) applying different research methods.

By systematizing a comprehensive collection of approaches currently available to support sustainability/CE-oriented BMI, the research provides contributions for:

- Practitioners: an overview of existing approaches for sustainability-oriented or CE-oriented BMI on the basis of dynamic capabilities;

- Researchers: a starting point for understanding the foundations of approaches, providing guidance on where to focus future research; and,

- Research community: advancing the discussions about the intersection between CE-oriented and sustainability-oriented BMI literature.

Limitations of this research are related to techniques applied for the literature review. The search in academic databases was followed by snowballing and inclusion of non-peer reviewed materials from specialist institutions, which by nature may generate selection bias. Moreover, the fast development of the field has led to many new publications within a short interval. Many analyzed approaches are still being validated/refined, therefore their usefulness has not yet been confirmed in all cases.

As mentioned, challenges identified by this research require future empirical work. This paper documents the first step of a comprehensive research to propose a CE-oriented BMI approach, but with a broader view of sustainability performance, based on best available practices. The proposed approach will be codeveloped with industry in action research cycles. Case studies will test the application of the approach and explore what are the specific BM patterns/configurations favoring a sustainable CE in different contexts.

\section{Acknowledgements}

Sent as separate text.

\section{References}

Accenture, 2014. Circular Advantage: Innovative Business Models and Technologies to Create Value in a World without Limits to Growth. https://www.accenture.com/t20150523T053139_w_/usen/_acnmedia/Accenture/Conversion-Assets/DotCom/Documents/Global/PDF/Strategy_6/Accenture-CircularAdvantage-Innovative-Business-Models-Technologies-Value-Growth.pdf (accessed 30 June 2018).

Achterberg, E., Hinfelaar, J., Bocken, N., 2016. Master Circular Business With the Value Hill. Circle Economy, https://www.circle-economy.com/wp-content/uploads/2016/09/finance-white-paper-20160923.pdf (accessed 15 July 2015).

Adams, R.J., Smart, P., Huff, A.S., 2017. Shades of Grey: Guidelines for Working with the Grey Literature in Systematic Reviews for Management and Organizational Studies. Int. J. Manag. Rev. 19, 432-454. https://doi.org/10.1111/ijmr.12102

Aminoff, A., Valkokari, K., Antikainen, M., Kettunen, O., 2017. Exploring Disruptive Business Model Innovation for the Circular Economy, in: Campana G., Howlett R., Setchi R., C.B. (Ed.), Sustainable Design and Manufacturing 2017. SDM 2017. Springer, Cham, pp. 525-536. https://doi.org/10.1007/978-3-319-57078-5_50

Aminoff, A., Valkokari, K., Kettunen, O., 2016. Mapping Multidimensional Value(s) for Co-creation Networks in a Circular Economy. pp. 629-638. https://doi.org/10.1007/978-3-319-45390-3_54

Antikainen, M., Aminoff, A., Kettunen, O., Sundqvist-andberg, H., Paloheimo, H., 2017. Sustainable Design and Manufacturing 2017, Sustainable Design and Manufacturing 2017, Smart Innovation, Systems and Technologies. Springer International Publishing, Cham. https://doi.org/10.1007/978-3-319-57078-5

Antikainen, M., Valkokari, K., 2016. A Framework for Sustainable Circular Business Model Innovation. Technol. Innov. Manag. Rev. 6, 5-12. 
Asif, F.M.A., Lieder, M., Rashid, A., 2016. Multi-method simulation based tool to evaluate economic and environmental performance of circular product systems. J. Clean. Prod. 139, 1261-1281. https://doi.org/10.1016/j.jclepro.2016.08.122

Bakker, C., Den Hollander, M., Van Hinte, E., Zljlstra, Y., 2014. Products that last: Product design for circular business models.

Baldassarre, B., Calabretta, G., Bocken, N.M.P., Jaskiewicz, T., 2017. Bridging sustainable business model innovation and user-driven innovation: A process for sustainable value proposition design. J. Clean. Prod. 147, 175-186. https://doi.org/10.1016/j.jclepro.2017.01.081

Barber, K.D., Beach, R., Zolkiewski, J., 2012. Environmental sustainability: a value cycle research agenda. Prod. Plan. Control 23, 105-119. https://doi.org/10.1080/09537287.2011.591621

Barquet, A.P., Seidel, J., Seliger, G., Kohl, H., 2016. Sustainability Factors for PSS Business Models. Procedia CIRP 47, 436-441. https://doi.org/10.1016/j.procir.2016.03.021

Biloslavo, R., Bagnoli, C., Edgar, D., 2018. An eco-critical perspective on business models: The value triangle as an approach to closing the sustainability gap. J. Clean. Prod. 174, 746-762. https://doi.org/10.1016/j.jclepro.2017.10.281

Birkin, F., Polesie, T., Lewis, L., 2009. A new business model for sustainable development: an exploratory study using the theory of constraints in Nordic organizations. Bus. Strateg. Environ. 18, 277-290. https://doi.org/10.1002/bse.581

Blomsma, F., Brennan, G., 2017. The Emergence of Circular Economy: A New Framing Around Prolonging Resource Productivity. J. Ind. Ecol. 21, 603-614. https://doi.org/10.1111/jiec.12603

Bocken, N., Short, S., Rana, P., Evans, S., 2013. A value mapping tool for sustainable business modelling. Corp. Gov. Int. J. Bus. Soc. 13, 482-497. https://doi.org/10.1108/CG-06-2013-0078

Bocken, N.M.P., de Pauw, I., Bakker, C., van der Grinten, B., 2016. Product design and business model strategies for a circular economy. J. Ind. Prod. Eng. 33, 308-320. https://doi.org/10.1080/21681015.2016.1172124

Bocken, N.M.P., Rana, P., Short, S.W., 2015. Value mapping for sustainable business thinking. J. Ind. Prod. Eng. 32, 67-81. https://doi.org/10.1080/21681015.2014.1000399

Bocken, N.M.P., Schuit, C.S.C., Kraaijenhagen, C., 2018. Experimenting with a circular business model: Lessons from eight cases. Environ. Innov. Soc. Transitions 28, 79-95. https://doi.org/10.1016/j.eist.2018.02.001

Bocken, N.M.P., Short, S.W., 2016. Towards a sufficiency-driven business model: Experiences and opportunities. Environ. Innov. Soc. Transitions 18, 41-61. https://doi.org/10.1016/j.eist.2015.07.010

Bocken, N.M.P., Short, S.W., Rana, P., Evans, S., 2014. A literature and practice review to develop sustainable business model archetypes. J. Clean. Prod. 65, 42-56. https://doi.org/10.1016/j.jclepro.2013.11.039

Boons, F., Lüdeke-Freund, F., 2013. Business models for sustainable innovation: state-of-the-art and steps towards a research agenda. J. Clean. Prod. 45, 9-19. https://doi.org/10.1016/j.jclepro.2012.07.007

Boons, F., Montalvo, C., Quist, J., Wagner, M., 2013. Sustainable innovation, business models and economic performance: an overview. J. Clean. Prod. 45, 1-8. https://doi.org/10.1016/j.jclepro.2012.08.013

Brehmer, M., Podoynitsyna, K., Langerak, F., 2018. Sustainable business models as boundary-spanning systems of value transfers. J. Clean. Prod. 172, 4514-4531. https://doi.org/10.1016/j.jclepro.2017.11.083

Breuer, H., Fichter, K., Freund, F.L., Tiemann, I., 2018. Sustainability-oriented business model development: principles, criteria and tools. Int. J. Entrep. Ventur. 10, 256. https://doi.org/10.1504/IJEV.2018.092715

Breuer, H., Lüdeke-Freund, F., 2014. Normative Innovation for Sustainable Business Models in Value Networks, in: The Proceedings of XXV ISPIM Conference-Innovation for Sustainable Economy and Society. p. 17.

Brones, F., Monteiro de Carvalho, M., 2015. From 50 to 1: integrating literature toward a systemic ecodesign model. J. Clean. Prod. 96, 44-57. https://doi.org/10.1016/j.jclepro.2014.07.036

BSI, 2017. BS 8001:2017. Framework for Implementing the Principles of the Circular Economy in Organizations Guide.

Ceschin, F., 2013. Critical factors for implementing and diffusing sustainable product-Service systems: Insights from innovation studies and companies' experiences. J. Clean. Prod. 45, 74-88. https://doi.org/10.1016/j.jclepro.2012.05.034

Chapman, J.A., 2002. A framework for transformational change in organisations. Leadersh. Organ. Dev. J. 23, 1625. https://doi.org/10.1108/01437730210414535 
Chiu, M.C., Kuo, M.Y., Kuo, T.C., 2015. A systematic methodology to develop business model of a product service system. Int. J. Ind. Eng. 22, 369-381.

CircleLab, 2018. Knowledge hub: case studies and articles. https://circle-lab.com/knowledge-hub/all-content (accessed 20 June 2018).

de Almeida Biolchini, J.C., Mian, P.G., Natali, A.C.C., Conte, T.U., Travassos, G.H., 2007. Scientific research ontology to support systematic review in software engineering. Adv. Eng. Informatics 21, 133-151. https://doi.org/10.1016/j.aei.2006.11.006

de Jong, E., Engelaer, F., Morice, M., 2015. Realizing opportunities of a circular business model [WWW Document]. URL http://images.info.yoursolutionspartner.com/Web/servicedllgroupcom/\%7Bee927947-b65e-4360-a15379b0f9ed68d7\%7D_Whitepaper_-

_Realizing_opportunities_of_a_circular_business_model.pdf?elqaid=71\&elqat=2\&elqTrackId=2f5d60d79e744 ee599ecea50b13497e9 (accessed 7.1.17).

de Pádua Pieroni, M., Pigosso, D.C.A., McAloone, T.C., 2018. Sustainable Qualifying Criteria for Designing Circular Business Models. Procedia CIRP 69, 799-804. https://doi.org/10.1016/j.procir.2017.11.014

Demil, B., Lecocq, X., 2010. Business Model Evolution: In Search of Dynamic Consistency. Long Range Plann. 43, 227-246. https://doi.org/10.1016/j.lrp.2010.02.004

Den Hollander, M., Bakker, C., 2016. Mind the Gap Exploiter: Circular Business Models for Product Lifetime Extension, in: Proceedings of Electronic Goes Green 2016+. Fraunhofer IZM Berlin, Berlin, pp. 1-8.

Dentchev, N., Rauter, R., Jóhannsdóttir, L., Snihur, Y., Rosano, M., Baumgartner, R., Nyberg, T., Tang, X., van Hoof, B., Jonker, J., 2018. Embracing the variety of sustainable business models: A prolific field of research and a future research agenda. J. Clean. Prod. 194, 695-703. https://doi.org/10.1016/j.jclepro.2018.05.156

Dewulf, K.R., 2010. Play it forward: A Game-based tool for Sustainable Product and Business Model Innovation in the Fuzzy Front End, in: Knowledge Collaboration \& Learning for Sustainable Innovation, Proceedings of the ERSCP-EMSU Conference, Delft, The Netherlands. pp. 1-16.

Diaz Lopez, F.J., Bastein, T., Tukker, A., 2019. Business Model Innovation for Resource-efficiency, Circularity and Cleaner Production: What 143 Cases Tell Us. Ecol. Econ. 155, 20-35. https://doi.org/10.1016/j.ecolecon.2018.03.009

Dresch, A., Lacerda, D.P., Antunes Jr., J.A.V., 2015. Design Science Research. Springer International Publishing, Cham, Switzerland. https://doi.org/10.1007/978-3-319-07374-3

EMF, 2018. Circular Economy Case Studies. https://www.ellenmacarthurfoundation.org/case-studies (accessed 23 September 2018).

EMF, 2016. The Circular Design Guide. Ellen McArthur Foundation Publishing, https://www.circulardesignguide.com (accessed 01 December 2017).

EMF, 2015. Towards a Circular Economy: business rationale for an accelerated transition. https://www.ellenmacarthurfoundation.org/assets/downloads/TCE_Ellen-MacArthur-Foundation_9-Dec2015.pdf (accessed 30 June 2018).

EMF, 2012. Towards the Circular Economy Vol. 1: Economic and business rationale for an accelerated transition. Ellen MacArthur Foundation Publishing, https://www.ellenmacarthurfoundation.org/assets/downloads/publications/Ellen-MacArthur-FoundationTowards-the-Circular-Economy-vol.1.pdf (accessed 01 December 2017).

European Comission, 2016. Circular economy financing: Support through Horizon 2020, Making it happen: European Commission seminar on circular economy financing. http://ec.europa.eu/environment/circulareconomy/pdf/seminar/7 DG RTD_Public support for CE Support though Horizon 2020.pdf (accessed 30 June 2018).

European Commission, 2018. Monitoring framework for the circular economy. https://eur-lex.europa.eu/legalcontent/EN/TXT/?qid=1516265440535\&uri=COM:2018:29:FIN (accessed 30 June 2018).

European Commission, 2014. Towards a circular economy: A zero waste programme for Europe. http://eurlex.europa.eu/legal-content/EN/TXT/?uri=CELEX:52014DC0398R\%2801\%29 (accessed 02 February 2018).

Evans, J., Bocken, N., 2013. CE Toolkit, Circular Economy Toolkit. http://circulareconomytoolkit.org/Toolkit.html (accessed 30 July 2017).

Evans, S., Fernando, L., Yang, M., 2017a. Sustainable Manufacturing, Sustainable Production, Life Cycle 
Engineering and Management. Springer International Publishing, Cham. https://doi.org/10.1007/978-3-31948514-0

Evans, S., Vladimirova, D., Holgado, M., Van Fossen, K., Yang, M., Silva, E.A., Barlow, C.Y., 2017b. Business Model Innovation for Sustainability: Towards a Unified Perspective for Creation of Sustainable Business Models. Bus. Strateg. Environ. 26, 597-608. https://doi.org/10.1002/bse.1939

Forum for the Future, 2016. The Circular Economy Business Model Toolkit. https://www.forumforthefuture.org/project/circular-economy-business-model-toolkit/overview (accessed 30 July 2017).

Foss, N.J., Saebi, T., 2017. Fifteen Years of Research on Business Model Innovation. J. Manage. 43, $200-227$. https://doi.org/10.1177/0149206316675927

França, C.L., Broman, G., Robèrt, K.-H., Basile, G., Trygg, L., 2017. An approach to business model innovation and design for strategic sustainable development. J. Clean. Prod. 140, 155-166. https://doi.org/10.1016/j.jclepro.2016.06.124

Gassmann, O., Frankenberger, K., Sauer, R., 2016. Exploring the Field of Business Model Innovation. Springer International Publishing, Cham. https://doi.org/10.1007/978-3-319-41144-6

Geissdoerfer, M., Bocken, N.M.P., Hultink, E.J., 2016. Design thinking to enhance the sustainable business modelling process - A workshop based on a value mapping process. J. Clean. Prod. 135, 1218-1232. https://doi.org/10.1016/j.jclepro.2016.07.020

Geissdoerfer, M., Morioka, S.N., de Carvalho, M.M., Evans, S., 2018a. Business models and supply chains for the circular economy. J. Clean. Prod. 190, 712-721. https://doi.org/10.1016/j.jclepro.2018.04.159

Geissdoerfer, M., Savaget, P., Bocken, N.M.P., Hultink, E.J., 2017a. The Circular Economy - A new sustainability paradigm? J. Clean. Prod. 143, 757-768. https://doi.org/10.1016/j.jclepro.2016.12.048

Geissdoerfer, M., Savaget, P., Evans, S., 2017b. The Cambridge Business Model Innovation Process. Procedia Manuf. 8, 262-269. https://doi.org/10.1016/j.promfg.2017.02.033

Geissdoerfer, M., Vladimirova, D., Evans, S., 2018b. Sustainable business model innovation: A review. J. Clean. Prod. 198, 401-416. https://doi.org/10.1016/j.jclepro.2018.06.240

Ghisellini, P., Cialani, C., Ulgiati, S., 2016. A review on circular economy: the expected transition to a balanced interplay of environmental and economic systems. J. Clean. Prod. 114, 11-32.

https://doi.org/10.1016/j.jclepro.2015.09.007

Girotra, K., Netessine, S., 2013. OM Forum -Business Model Innovation for Sustainability. Manuf. Serv. Oper. Manag. 15, 537-544. https://doi.org/10.1287/msom.2013.0451

Haanstra, W., Toxopeus, M.E., van Gerrevink, M.R., 2017. Product Life Cycle Planning for Sustainable Manufacturing: Translating Theory into Business Opportunities. Procedia CIRP 61, 46-51. https://doi.org/10.1016/j.procir.2016.12.005

Hahn, R., Spieth, P., Ince, I., 2018. Business model design in sustainable entrepreneurship: Illuminating the commercial logic of hybrid businesses. J. Clean. Prod. 176, 439-451. https://doi.org/10.1016/j.jclepro.2017.12.167

Halme, M., Anttonen, M., Kuisma, M., Kontoniemi, N., Heino, E., 2007. Business models for material efficiency services: Conceptualization and application. Ecol. Econ. 63, 126-137. https://doi.org/10.1016/j.ecolecon.2006.10.003

Holgado, M., Corti, D., Macchi, M., Rana, P., Short, S., Evans, S., 2013. Business Modelling for Sustainable Manufacturing, in: Advances in Production Management Systems. Competitive Manufacturing for Innovative Products and Services. pp. 166-174. https://doi.org/10.1007/978-3-642-40352-1_22

Inigo, E.A., Albareda, L., Ritala, P., 2017. Business model innovation for sustainability: exploring evolutionary and radical approaches through dynamic capabilities. Ind. Innov. 24, 515-542. https://doi.org/10.1080/13662716.2017.1310034

Jabłoński, A., Jabłoński, M., 2016. Research on Business Models in their Life Cycle. Sustainability 8, 430. https://doi.org/10.3390/su8050430

Jones, P., Upward, A., 2014. Caring for the Future: The Systemic Design of Flourishing Enterprises. https://www.academia.edu/9338233/Caring_for_the_Future_The_Systemic_Design_of_Flourishing_Enterprises (accessed 30 June 2018). 
Joustra, D.J., de Jong, E., Engelaer, F., 2013. Guided Choices towards a Circular Business Model. Project C2C Bizz, http://www.c2cbizz.com/tools/c2c-bizz-guide-en.pdf\%0A (accessed 30 July 2017).

Joyce, A., 2017. Managing Complexity, Managing Complexity, Springer Proceedings in Business and Economics. Springer International Publishing, Cham. https://doi.org/10.1007/978-3-319-29058-4

Joyce, A., Paquin, R.L., 2016. The triple layered business model canvas: A tool to design more sustainable business models. J. Clean. Prod. 135, 1474-1486. https://doi.org/10.1016/j.jclepro.2016.06.067

Khripko, D., Morioka, S.N., Evans, S., Hesselbach, J., de Carvalho, M.M., 2017. Demand Side Management within Industry: A Case Study for Sustainable Business Models. Procedia Manuf. 8, $270-277$. https://doi.org/10.1016/j.promfg.2017.02.034

Kraaijenhagen, C., Van Open, C., Bocken, N., 2016. Circular Business Collaborate and Circulate. Circular Collaboration, The Netherlands.

Kurucz, E.C., Colbert, B.A., Lüdeke-Freund, F., Upward, A., Willard, B., 2017. Relational leadership for strategic sustainability: practices and capabilities to advance the design and assessment of sustainable business models. J. Clean. Prod. 140, 189-204. https://doi.org/10.1016/j.jclepro.2016.03.087

Laasch, O., 2018. Beyond the purely commercial business model: Organizational value logics and the heterogeneity of sustainability business models. Long Range Plann. 51, 158-183. https://doi.org/10.1016/j.lrp.2017.09.002

Lacy, P., Rosenber, D., Drewell, Q., Rutqvist, J., 2013. 5 business models that are driving the circular economy. https://www.fastcompany.com/1681904/5-business-models-that-are-driving-the-circular-economy (accessed 30 June 2018).

Laubscher, M., Marinelli, T., 2014. Integration of Circular Economy in Business, in: Going Green - CARE INNOVATION. Vienna, Austria.

Lee, E., 2016. Service Design Challenge: Transitioning From Concept to Implementation. 228-240 228-240.

Lewandowski, M., 2016. Designing the Business Models for Circular Economy-Towards the Conceptual Framework. Sustainability 8, 43. https://doi.org/10.3390/su8010043

Lieder, M., Asif, F.M.A., Rashid, A., 2017. Towards Circular Economy implementation: an agent-based simulation approach for business model changes. Auton. Agent. Multi. Agent. Syst. 31, 1377-1402. https://doi.org/10.1007/s10458-017-9365-9

Linder, M., Williander, M., 2017. Circular Business Model Innovation: Inherent Uncertainties. Bus. Strateg. Environ. 26, 182-196. https://doi.org/10.1002/bse.1906

Lüdeke-Freund, F., 2010. Towards a Conceptual Framework of Business Models for Sustainability, in: Knowledge Collaboration \& Learning for Sustainable Innovation ERSCP-EMSU Conference, Delft, The Netherlands. pp. 1-28. https://doi.org/10.13140/ RG.2.1.2565.0324

Lüdeke-Freund, F., Dembek, K., 2017. Sustainable business model research and practice: Emerging field or passing fancy? J. Clean. Prod. 168, 1668-1678. https://doi.org/10.1016/j.jclepro.2017.08.093

Lüdeke-Freund, F., Gold, S., Bocken, N.M.P., 2018. A Review and Typology of Circular Economy Business Model Patterns. J. Ind. Ecol. 00, 1-72. https://doi.org/10.1111/jiec.12763

Magretta, J., 2002. Why Business Models Matter, Harvard Business Review. https://hbr.org/2002/05/why-businessmodels-matter (accessed 30 June 2018).

Manninen, K., Koskela, S., Antikainen, R., Bocken, N., Dahlbo, H., Aminoff, A., 2018. Do circular economy business models capture intended environmental value propositions? J. Clean. Prod. 171, 413-422. https://doi.org/10.1016/j.jclepro.2017.10.003

Massa, L., Tucci, C.L., 2014. Business Model Innovation, The Oxford Handbook of Innovation Management. Oxford University Press. https://doi.org/10.1093/oxfordhb/9780199694945.013.002

Materials, E.R., 2016. EU Circulator, Circular Business Model Mixer. http://www.circulator.eu/about (accessed 30 June 2018).

Mendoza, J.M.F., Sharmina, M., Gallego-Schmid, A., Heyes, G., Azapagic, A., 2017. Integrating Backcasting and Eco-Design for the Circular Economy: The BECE Framework. J. Ind. Ecol. 21, 526-544. https://doi.org/10.1111/jiec.12590

Mentink, B. a S., 2014. Circular Business Model Innovation A process framework and a tool for business model innovation in a circular economy. Master Theis. Delft University of Technology and Leiden University.

Merli, R., Preziosi, M., Acampora, A., 2018. How do scholars approach the circular economy? A systematic 
literature review. J. Clean. Prod. 178, 703-722. https://doi.org/10.1016/j.jclepro.2017.12.112

Mezger, F., 2014. Toward a capability-based conceptualization of business model innovation.de: insights from an explorative study. R\&D Manag. 44, 429-449. https://doi.org/10.1111/radm.12076

Moreno, M., De los Rios, C., Rowe, Z., Charnley, F., 2016. A Conceptual Framework for Circular Design. Sustainability 8, 937. https://doi.org/10.3390/su8090937

Morioka, S.N., Bolis, I., Carvalho, M.M. de, 2018. From an ideal dream towards reality analysis: Proposing Sustainable Value Exchange Matrix (SVEM) from systematic literature review on sustainable business models and face validation. J. Clean. Prod. 178, 76-88. https://doi.org/10.1016/j.jclepro.2017.12.078

Morioka, S.N., Bolis, I., Evans, S., Carvalho, M.M., 2017. Transforming sustainability challenges into competitive advantage: Multiple case studies kaleidoscope converging into sustainable business models. J. Clean. Prod. 167, 723-738. https://doi.org/10.1016/j.jclepro.2017.08.118

National Zero Waste Council, 2016. Circular Economy Business Toolkit, National Zero Waste Council of Canada. http://www.nzwc.ca/Documents/CircularEconomyBusinessToolkit.pdf (accessed 20.07.2017).

Nußholz, J., 2017. Circular Business Models: Defining a Concept and Framing an Emerging Research Field. Sustainability 9, 1810. https://doi.org/10.3390/su9101810

Nußholz, J.L.K., 2018. A circular business model mapping tool for creating value from prolonged product lifetime and closed material loops. J. Clean. Prod. 197, 185-194. https://doi.org/10.1016/j.jclepro.2018.06.112

Osterwalder, A., Pigneur, Y., 2010. Business Model Generation. Self Published, Amsterdam.

Osterwalder, A., Pigneur, Y., Tucci, C.L., 2005. Clarifying Business Models : Origins, Present, and Future of the Concept. Commun. Assoc. Inf. Syst. 16, 1-25.

Panarotto, M., Törlind, P., 2011. Sustainability innovation in early phases. ICED 11 - 18th Int. Conf. Eng. Des. Impacting Soc. Through Eng. Des. 5, 187-197.

Phaal, R., Farrukh, C., Probert, D., 2004. Customizing roadmapping. IEEE Eng. Manag. Rev. 32, 80-80. https://doi.org/10.1109/EMR.2004.25111

Pieroni, M., Pigosso, D., McAloone, T., 2018. Exploring the synergistic relationships of circular business model development and product design., in: INTERNATIONAL DESIGN CONFERENCE - DESIGN 2018. pp. 2715-2726. https://doi.org/10.21278/idc.2018.0202

Pigosso, D., Rozenfeld, Seliger, 2011. Advances in Sustainable Manufacturing, Advances in Sustainable Manufacturing. Springer Berlin Heidelberg, Berlin, Heidelberg. https://doi.org/10.1007/978-3-642-20183-7

Planing, P., 2018. Towards a circular economy - how business model innovation will help to make the shift. Int. J. Bus. Glob. 20, 71. https://doi.org/10.1504/IJBG.2018.088665

Prendeville, S., Bocken, N., 2017. Sustainable Business Models through Service Design. Procedia Manuf. 8, 292 299. https://doi.org/10.1016/j.promfg.2017.02.037

Randles, S., Laasch, O., 2016. Theorising the Normative Business Model. Organ. Environ. 29, 53-73. https://doi.org/10.1177/1086026615592934

REBus, 2015. Guide for suppliers REBMs. http://www.rebus.eu.com/implementing-a-rebm/guide-for-suppliersrebms/ (accessed 30 June 2018).

ResCoM, 2017. Lease or Buy. https://www.rescoms.eu/assets/images/Lease-or-Buy.pdf (accessed 30 June 2017).

Richardson, J., 2008. The business model: an integrative framework for strategy execution. Strateg. Chang. 17, 133144. https://doi.org/10.1002/jsc.821

Rohrbeck, R., Konnertz, L., Knab, S., 2013. Collaborative business modelling for systemic and sustainability innovations. Int. J. Technol. Manag. 63, 4. https://doi.org/10.1504/IJTM.2013.055577

Roome, N., Louche, C., 2016. Journeying Toward Business Models for Sustainability. Organ. Environ. 29, 11-35. https://doi.org/10.1177/1086026615595084

Roos, G., 2014. Business Model Innovation to Create and Capture Resource Value in Future Circular Material Chains. Resources 3, 248-274. https://doi.org/10.3390/resources3010248

Roos, G., Agarwal, R., 2015. The Handbook of Service Innovation, The Handbook of Service Innovation. Springer London, London. https://doi.org/10.1007/978-1-4471-6590-3

Rosa, M., Marques, C.A.N., Rozenfeld, H., 2017. Commonalities and Particularities of PSS Design Process and Design Thinking. Procedia CIRP 64, 253-258. https://doi.org/10.1016/j.procir.2017.03.020

Sakao, T., Brambila-Macias, S.A., 2018. Do we share an understanding of transdisciplinarity in environmental 
sustainability research? J. Clean. Prod. 170, 1399-1403. https://doi.org/10.1016/j.jclepro.2017.09.226

Schaltegger, S., Freund, F.L., Hansen, E.G., 2012. Business cases for sustainability: the role of business model innovation for corporate sustainability. Int. J. Innov. Sustain. Dev. 6, 95.

https://doi.org/10.1504/IJISD.2012.046944

Schaltegger, S., Hansen, E.G., Lüdeke-Freund, F., 2016a. Business Models for Sustainability. Organ. Environ. 29, 310. https://doi.org/10.1177/1086026615599806

Schaltegger, S., Lüdeke-Freund, F., Hansen, E.G., 2016b. Business Models for Sustainability. Organ. Environ. 29, 264-289. https://doi.org/10.1177/1086026616633272

Scheepens, A.E., Vogtländer, J.G., Brezet, J.C., 2016. Two life cycle assessment (LCA) based methods to analyse and design complex (regional) circular economy systems. Case: making water tourism more sustainable. J. Clean. Prod. 114, 257-268. https://doi.org/10.1016/j.jclepro.2015.05.075

Schoormann, T., Behrens, D., Kolek, E., Knackstedt, R., 2016. Sustainability in business models - a literaturereview-based Design-Science-oriented research agenda, in: Proceedings of the 24th European Conference on Information Systems. pp. 1-18.

Schoormann, T., Knackstedt, R., 2018. Towards Tool-supported Reflection of Sustainability in Business Models, in: 9th International Workshop on Enterprise Modeling and Information Systems Architectures (EMISA). pp. 610.

Sempels, C., 2013. Implementing a circular and performance economy through business model innovation, in: A New Dynamic Effective Business in a Circular Economy. Ellen McArthur Foundation Publishing, p. 171.

Short, S.W., Rana, P., Bocken, N.M.P., Evans, S., 2013. Advances in Production Management Systems. Competitive Manufacturing for Innovative Products and Services, Advances in Production Management Systems. Competitive Manufacturing for Innovative Products and Services, IFIP Advances in Information and Communication Technology. Springer Berlin Heidelberg, Berlin, Heidelberg. https://doi.org/10.1007/978-3642-40352-1

Stubbs, W., Cocklin, C., 2008. Conceptualizing a "Sustainability Business Model.” Organ. Environ. 21, 103-127. https://doi.org/10.1177/1086026608318042

Sustainn, 2017. Circularity Canvas: Methodology to Outline Circular Business Models. http://www.wearesustainn.com/en/2017/03/circularity-canvas-methodology-circular-business-models/ (accessed 30 June 2018).

Teece, D.J., 2010. Business Models, Business Strategy and Innovation. Long Range Plann. 43, 172-194. https://doi.org/10.1016/j.lrp.2009.07.003

Teece, D.J., 2007. Explicating dynamic capabilities: the nature and microfoundations of (sustainable) enterprise performance. Strateg. Manag. J. 28, 1319-1350. https://doi.org/10.1002/smj.640

Tiemann, I., Fichter, K., 2016. Developing business models with the Sustainable Business Canvas Manual for conducting workshops. http://startup4climate.de/wp-content/uploads/2015/03/Tiemann-FichterWorkshopkonzept-EN-RZ2.pdf (accessed 30 June 2018).

Tranfield, D., Denyer, D., Smart, P., 2003. Towards a Methodology for Developing Evidence-Informed Management Knowledge by Means of Systematic Review. Br. J. Manag. 14, 207-222. https://doi.org/10.1111/14678551.00375

Upward, A., Jones, P., 2016. An Ontology for Strongly Sustainable Business Models. Organ. Environ. 29, 97-123. https://doi.org/10.1177/1086026615592933

Urbinati, A., Chiaroni, D., Chiesa, V., 2017. Towards a new taxonomy of circular economy business models. J. Clean. Prod. 168, 487-498. https://doi.org/10.1016/j.jclepro.2017.09.047

van Renswoude, K., Wolde, A. ten, Joustra, D.J., 2015. Circular business models - Part 1: An introduction to IMSA's circular business model scan, IMSA Amsterdam. http://hh.surfsharekit.nl:8080/get/smpid:53447/DS1 (accessed 20 July 2017).

Vogtlander, J.G., Scheepens, A.E., Bocken, N.M.P., Peck, D., 2017. Combined analyses of costs, market value and eco-costs in circular business models: eco-efficient value creation in remanufacturing. J. Remanufacturing 7, 117. https://doi.org/10.1007/s13243-017-0031-9

Weetman, C., 2016. A Circular Economy Handbook for Business and Supply Chains: Repair, Remake, Redesign, Rethink. Kogan Page Publishers, New York. 
WEF, 2014. Towards the Circular Economy: accelerating the scale-up across global supply chains. Cologny, Switzerland: World Economic Forum.

Wells, P., 2016. Economies of Scale Versus Small Is Beautiful. Organ. Environ. 29, 36-52. https://doi.org/10.1177/1086026615590882

Wiithaa, 2018. Circulab Tools. https://circulab.eu/contact-us/ (accessed 30 June 2018).

Wirtz, B.W., Pistoia, A., Ullrich, S., Göttel, V., 2016. Business Models: Origin, Development and Future Research Perspectives. Long Range Plann. 49, 36-54. https://doi.org/10.1016/j.lrp.2015.04.001

Wohlin, C., 2014. Guidelines for snowballing in systematic literature studies and a replication in software engineering, in: Proceedings of the 18th International Conference on Evaluation and Assessment in Software Engineering - EASE'14. ACM Press, New York, New York, USA, pp. 1-10. https://doi.org/10.1145/2601248.2601268

WRAP, 2018. Innovative Business Models Map. http://www.wrap.org.uk/resource-efficient-businessmodels/innovative-business-models (accessed 30 June 2018).

Yang, M., Evans, S., Vladimirova, D., Rana, P., 2017. Value uncaptured perspective for sustainable business model innovation. J. Clean. Prod. 140, 1794-1804. https://doi.org/10.1016/j.jclepro.2016.07.102

Yang, M., Smart, P., Kumar, M., Jolly, M., Evans, S., 2018. Product-service systems business models for circular supply chains. Prod. Plan. Control 29, 498-508. https://doi.org/10.1080/09537287.2018.1449247

Yang, M., Vladimirova, D., Evans, S., 2017. Creating and Capturing Value Through Sustainability. Res. Manag. 60, 30-39. https://doi.org/10.1080/08956308.2017.1301001

Yang, M., Vladimirova, D., Rana, P., Evans, S., 2014. Sustainable value analysis tool for value creation. Asian J. Manag. Sci. Appl. 1, 312. https://doi.org/10.1504/AJMSA.2014.070649

Zott, C., Amit, R., 2010. Business Model Design: An Activity System Perspective. Long Range Plann. 43, $216-226$. https://doi.org/10.1016/j.lrp.2009.07.004

\section{Appendix}

Table 4. Approaches for sustainability-oriented and CE-oriented BMI. Legend for Origin: S= Sustainability; CE= Circular Economy; B=both.

\begin{tabular}{|c|c|c|c|}
\hline Code & Origin & Description & References \\
\hline AR01 & $\mathrm{S}$ & Framework for analyzing material efficiency services BMs. & (Halme et al., 2007) \\
\hline AR02 & $\mathrm{S}$ & $\begin{array}{l}\text { Framework with dimensions and characteristics for sustainability-oriented } \\
\text { BMs. }\end{array}$ & (Stubbs and Cocklin, 2008) \\
\hline AR03 & $\mathrm{S}$ & $\begin{array}{l}\text { Play it forward: game-based tool for designing BMs with sustainability } \\
\text { principles. }\end{array}$ & (Dewulf, 2010) \\
\hline AR04 & $\mathrm{S}$ & $\begin{array}{l}\text { BMI process for sustainability, combining transformational sustainability } \\
\text { strategies, eco-innovation, and key ideas about value creation. }\end{array}$ & $\begin{array}{l}\text { (Lüdeke-Freund, 2010; } \\
\text { Roos and Agarwal, 2015) }\end{array}$ \\
\hline AR05 & $\mathrm{S}$ & $\begin{array}{l}\text { Sustainable innovation workshop: framework of methods for sustainability } \\
\text { driven innovation. }\end{array}$ & $\begin{array}{l}\text { (Panarotto and Törlind, } \\
\text { 2011) }\end{array}$ \\
\hline AR06 & $\mathrm{S}$ & $\begin{array}{l}\text { Value cycle framework to embed sustainability in current views of supply } \\
\text { chain. }\end{array}$ & (Barber et al., 2012) \\
\hline AR07 & $\mathrm{S}$ & Framework of a business case for guiding sustainability-oriented BMI. & (Schaltegger et al., 2012) \\
\hline AR08 & $\mathrm{CE}$ & Workbook providing guidance on the search for CE-oriented BMs. & $\begin{array}{l}\text { (de Jong et al., 2015; } \\
\text { Joustra et al., 2013) }\end{array}$ \\
\hline AR09 & $C E$ & $\begin{array}{l}\text { Circular Economy Toolkit: information on how to find CE benefits in } \\
\text { several areas, including BMI. }\end{array}$ & (Evans and Bocken, 2013) \\
\hline AR10 & $\mathrm{S}$ & $\begin{array}{l}\text { Process for 'collaborative business modelling' to foster sustainability } \\
\text { innovation. }\end{array}$ & (Rohrbeck et al., 2013) \\
\hline AR11 & $\mathrm{S}$ & Systematic stage-gate process of innovation for sustainable firms. & $\begin{array}{l}\text { (Girotra and Netessine, } \\
\text { 2013; Roos and Agarwal, } \\
\text { 2015) }\end{array}$ \\
\hline AR12 & $\mathrm{S}$ & $\begin{array}{l}\text { Value Mapping Tool: for exploring value opportunities for sustainability- } \\
\text { oriented BMs. }\end{array}$ & $\begin{array}{l}\text { (Bocken et al., 2013, 2015; } \\
\text { Khripko et al., 2017; Short } \\
\text { et al., 2013) }\end{array}$ \\
\hline
\end{tabular}




\begin{tabular}{|c|c|c|c|}
\hline AR13 & $\mathrm{S}$ & $\begin{array}{l}\text { Process for embedding sustainability in BM design by analysing value } \\
\text { exchanges and exploring social and environmental values. }\end{array}$ & (Holgado et al., 2013) \\
\hline AR14 & S & Normative requirements of BMs for sustainable innovation. & $\begin{array}{l}\text { (Boons and Lüdeke- } \\
\text { Freund, 2013) }\end{array}$ \\
\hline AR15 & $\mathrm{CE}$ & Typology of 5 BMs for CE. & $\begin{array}{l}\text { (Accenture, 2014; Lacy et } \\
\text { al., 2013) }\end{array}$ \\
\hline AR16 & $\mathrm{CE}$ & Circular BM Innovation Framework: process to plan the BMI for CE. & (Mentink, 2014) \\
\hline AR17 & $\mathrm{CE}$ & $\begin{array}{l}\text { Business Cycle Canvas: tool for designing BMs for CE with focus on the } \\
\text { network view. }\end{array}$ & (Mentink, 2014) \\
\hline AR18 & $\mathrm{CE}$ & $\begin{array}{l}\text { Extended version of BM Canvas to support the design of BMs for CE, still } \\
\text { with firm-centric view. }\end{array}$ & (Mentink, 2014) \\
\hline AR19 & S & $\begin{array}{l}\text { Sustainable Value Analysis Tool: for identifying opportunities for } \\
\text { sustainable value creation during product/service system (PSS) } \\
\text { development. }\end{array}$ & $\begin{array}{l}\text { (Yang et al., 2014; Miying } \\
\text { Yang et al., 2017) }\end{array}$ \\
\hline AR20 & $\mathrm{S}$ & $\begin{array}{l}\text { Business Innovation Kit: game-based tool for designing BMs for sustainable } \\
\text { value networks. }\end{array}$ & $\begin{array}{l}\text { (Breuer and Lüdeke- } \\
\text { Freund, 2014) }\end{array}$ \\
\hline AR21 & S & $\begin{array}{l}\text { Strongly Sustainable BM Canvas: tool for designing strongly sustainable } \\
\text { BMs. }\end{array}$ & $\begin{array}{l}\text { (Jones and Upward, 2014; } \\
\text { Kurucz et al., 2017) }\end{array}$ \\
\hline AR22 & $\mathrm{CE}$ & Process for developing BMs for circular value chains. & $\begin{array}{l}\text { (Roos, 2014; Roos and } \\
\text { Agarwal, 2015) }\end{array}$ \\
\hline AR23 & $\mathrm{CE}$ & $\begin{array}{l}\text { Framework showing how companies could integrate CE principles by } \\
\text { changing business processes, including BMI. }\end{array}$ & $\begin{array}{l}\text { (Laubscher and Marinelli, } \\
\text { 2014) }\end{array}$ \\
\hline AR24 & $\mathrm{S}$ & Typology of 8 BMs archetypes for sustainability. & (Bocken et al., 2014) \\
\hline AR25 & $\mathrm{CE}$ & BM archetypes for CE. & (Bakker et al., 2014) \\
\hline AR26 & $\mathrm{CE}$ & Framework for aligning product design and BM design strategies for CE. & (Bakker et al., 2014) \\
\hline AR27 & $\mathrm{CE}$ & $\begin{array}{l}\text { Circular BM Scan: method for CE transition, including insights on what } \\
\text { BMs to adopt (typology of } 19 \mathrm{BMs} \text { ) and implementation burdens. }\end{array}$ & $\begin{array}{l}\text { (van Renswoude et al., } \\
\text { 2015) }\end{array}$ \\
\hline AR28 & $\mathrm{CE}$ & $\begin{array}{l}\text { Methodology for developing BMs of PSS based on internal capability and } \\
\text { external environment factors. }\end{array}$ & (Chiu et al., 2015) \\
\hline AR29 & $\mathrm{CE}$ & $\begin{array}{l}\text { Circulab Game: } 3 \text { game-based tools for 'ecodesigning' BMs, exploring } \\
\text { relationships with partners and planning the evolution over time. }\end{array}$ & (Wiithaa, 2018) \\
\hline AR30 & $\mathrm{CE}$ & $\begin{array}{l}\text { CE Business Toolkit: to develop a circular strategy by identifying strategic } \\
\text { opportunities, analysing value chain, and choosing BM options. }\end{array}$ & $\begin{array}{l}\text { (National Zero Waste } \\
\text { Council, 2016) }\end{array}$ \\
\hline AR31 & S & $\begin{array}{l}\text { Sustainable BM Canvas Tool: for designing BMs based on circular and } \\
\text { performance economy. }\end{array}$ & (Sempels, 2013) \\
\hline AR32 & $\mathrm{CE}$ & $\begin{array}{l}\text { Adaptation of BM Canvas for joint application with other tools from a } \\
\text { Circular Design Guide. }\end{array}$ & (EMF, 2016) \\
\hline AR33 & $\mathrm{CE}$ & $\begin{array}{l}\text { CE BM Toolkit: created by Unilever to inspire the development of circular } \\
\text { systems based on circular BM archetypes. }\end{array}$ & $\begin{array}{l}\text { (Forum for the Future, } \\
\text { 2016) }\end{array}$ \\
\hline AR34 & $\mathrm{S}$ & $\begin{array}{l}\text { Framework integrating existing approaches of value mapping and design } \\
\text { thinking to support creating value propositions. }\end{array}$ & (Geissdoerfer et al., 2016) \\
\hline AR35 & $\mathrm{CE}$ & $\begin{array}{l}\text { Circular BMs Mixer: web-based tool providing an overview of the most } \\
\text { relevant BMs for raw materials industry in the context of CE. }\end{array}$ & (Materials, 2016) \\
\hline AR36 & $\mathrm{CE}$ & $\begin{array}{l}\text { Value Hill: tool for identifying gaps and opportunities for the transition to } \\
\text { CE, involving new BMs. }\end{array}$ & (Achterberg et al., 2016) \\
\hline AR37 & B & $\begin{array}{l}\text { Framework for Sustainable Circular BMI: tool for designing and } \\
\text { reconfiguring BMs for CE. }\end{array}$ & $\begin{array}{l}\text { (Antikainen and Valkokari, } \\
\text { 2016) }\end{array}$ \\
\hline AR38 & B & $\begin{array}{l}\text { Circular Transition Framework: for sustainability-oriented BM design based } \\
\text { on analysing potential negative environmental effects of initiatives. }\end{array}$ & (Scheepens et al., 2016) \\
\hline AR39 & $\mathrm{CE}$ & $\begin{array}{l}\text { Multi-method simulation tool to evaluate economic and environmental } \\
\text { performance of circular-oriented BM systems. }\end{array}$ & $\begin{array}{l}\text { (Asif et al., 2016; Lieder et } \\
\text { al., 2017) }\end{array}$ \\
\hline AR40 & $\mathrm{CE}$ & $\begin{array}{l}\text { Circular BM Canvas: conceptual framework to support the transition from } \\
\text { linear to more circular-oriented BMs. }\end{array}$ & (Lewandowski, 2016) \\
\hline AR41 & S & $\begin{array}{l}\text { Triple Layered BM Canvas: tool for exploring sustainability-oriented BMI in } \\
\text { the creative conceptual phase. }\end{array}$ & $\begin{array}{l}\text { (Joyce, 2017; Joyce and } \\
\text { Paquin, 2016) }\end{array}$ \\
\hline AR42 & $\mathrm{S}$ & Strongly Sustainable BM Ontology: for modelling sustainability-oriented & (Upward and Jones, 2016) \\
\hline
\end{tabular}




\begin{tabular}{|c|c|c|c|}
\hline & & businesses. & \\
\hline AR43 & $\mathrm{CE}$ & $\begin{array}{l}\text { Framework for mapping multidimensional value(s) for co-creation networks } \\
\text { in CE. }\end{array}$ & (Aminoff et al., 2016) \\
\hline AR44 & $\mathrm{CE}$ & $\begin{array}{l}10 \text { steps process model for the creation of circular businesses within existing } \\
\text { organizations. }\end{array}$ & (Kraaijenhagen et al., 2016) \\
\hline AR45 & B & Sustainable BM Framework: tool for designing sustainability-oriented BMs. & (Kraaijenhagen et al., 2016) \\
\hline AR46 & $\mathrm{CE}$ & $\begin{array}{l}\text { Strategic process for implementation of BMs for CE inspired by whole- } \\
\text { system design. }\end{array}$ & (Weetman, 2016) \\
\hline AR47 & CE & $\begin{array}{l}\text { Game-based tool for whole systems design and identification of BMs for } \\
\text { CE. }\end{array}$ & (Weetman, 2016) \\
\hline AR48 & $\mathrm{S}$ & $\begin{array}{l}\text { Theoretical model to guide the organisational transformation required for } \\
\text { implementing BMs for sustainability. }\end{array}$ & (Randles and Laasch, 2016) \\
\hline AR49 & $\mathrm{CE}$ & Framework of strategies for BM and product design for CE. & (Bocken et al., 2016) \\
\hline AR50 & $\mathrm{CE}$ & $\begin{array}{l}\text { Systematization of BM archetypes and framework to link BM and design } \\
\text { strategies for CE. }\end{array}$ & (Moreno et al., 2016) \\
\hline AR51 & $\mathrm{CE}$ & CE Framework: overview of commercial models for CE. & (Weetman, 2016) \\
\hline AR52 & S & $\begin{array}{l}\text { Process model of BM development and organizational transformation for } \\
\text { sustainability. }\end{array}$ & (Roome and Louche, 2016) \\
\hline AR53 & $\mathrm{B}$ & $\begin{array}{l}\text { Sustainable BM Framework: tool to support the design of BMs for } \\
\text { sustainability or CE. }\end{array}$ & (Bocken and Short, 2016) \\
\hline AR54 & $\mathrm{S}$ & Typology for three levels and key changes towards BM for sustainability. & $\begin{array}{l}\text { (Jabłoński and Jabłoński, } \\
\text { 2016) }\end{array}$ \\
\hline AR55 & $\mathrm{S}$ & $\begin{array}{l}5 \text { main factors and respective subfactors that lead to sustainability in BM } \\
\text { design of PSS. }\end{array}$ & (Barquet et al., 2016) \\
\hline AR56 & $\mathrm{S}$ & $\begin{array}{l}\text { Analytical framework to describe the sustainable entrepreneurship process } \\
\text { from BMI to diffusion of sustainability-oriented BM in the mass market. }\end{array}$ & (Schaltegger et al., 2016b) \\
\hline AR57 & $\mathrm{S}$ & $\begin{array}{l}\text { Sustainable Business Canvas: tool and manual for designing sustainability- } \\
\text { oriented BMs based on workshops. }\end{array}$ & $\begin{array}{l}\text { (Tiemann and Fichter, } \\
\text { 2016) }\end{array}$ \\
\hline AR58 & $\mathrm{S}$ & $\begin{array}{l}\text { Framework to guide manufacturing companies in identifying value } \\
\text { uncaptured to trigger the discovery of new sustainable value opportunities. }\end{array}$ & (M. Yang et al., 2017) \\
\hline AR59 & $\mathrm{CE}$ & $\begin{array}{l}\text { Backcasting and Eco-design for CE (BECE): framework for aiding business } \\
\text { in implementing CE requirements in BMs. }\end{array}$ & (Mendoza et al., 2017) \\
\hline AR60 & $\mathrm{S}$ & $\begin{array}{l}\text { Requirements and characteristics for the development of sustainability- } \\
\text { oriented BM tools. }\end{array}$ & (Evans et al., 2017b) \\
\hline AR61 & $\mathrm{S}$ & $\begin{array}{l}\text { Morphological matrix for circular development: framework providing } \\
\text { guidelines for implementation of circular and sustainable principles in BM } \\
\text { development. }\end{array}$ & (Haanstra et al., 2017) \\
\hline AR62 & $\mathrm{CE}$ & Framework for shaping industrial systems towards CE ecosystems. & (Aminoff et al., 2017) \\
\hline AR63 & $\mathrm{S}$ & $\begin{array}{l}\text { Framework for Strategic Sustainable Development (FSSD): for BM } \\
\text { innovation and design based on backasting and sustainable principles. }\end{array}$ & $\begin{array}{l}\text { (França et al., 2017; } \\
\text { Kurucz et al., 2017) }\end{array}$ \\
\hline AR64 & $\mathrm{S}$ & Process model for sustainable value proposition design. & (Baldassarre et al., 2017) \\
\hline AR65 & $\mathrm{CE}$ & Questions/criteria for risk assessment and checking in the BM design. & $\begin{array}{l}\text { (Linder and Williander, } \\
\text { 2017) }\end{array}$ \\
\hline AR66 & CE & $\begin{array}{l}\text { Lease or buy: game-based tool for exploring the implications of choosing } \\
\text { ownership-based or access-based BMs. }\end{array}$ & (ResCoM, 2017) \\
\hline AR67 & $\mathrm{CE}$ & $\begin{array}{l}\text { Guide for suppliers Resource Efficient BMs (REBMs): process model to } \\
\text { guide the implementation of resource efficient BMs. }\end{array}$ & (REBus, 2015) \\
\hline AR68 & $\mathrm{CE}$ & $\begin{array}{l}\text { Innovative BMs Map: typology of BMs for CE with accompanying case } \\
\text { studies. }\end{array}$ & (WRAP, 2018) \\
\hline AR69 & $\mathrm{S}$ & $\begin{array}{l}\text { Framework of sensing, seizing and reconfiguring capabilities in categories } \\
\text { (evolutionary and radical) of BMI for sustainability. }\end{array}$ & (Inigo et al., 2017) \\
\hline AR70 & $\mathrm{S}$ & $\begin{array}{l}\text { Cambridge BMI Process: framework for sustainability-oriented BM } \\
\text { generation from early conceptualisation to implementation. }\end{array}$ & (Geissdoerfer et al., 2017b) \\
\hline AR71 & $\mathrm{CE}$ & $\begin{array}{l}\text { Taxonomy of CE BMs based on the degree of adoption of circular principles } \\
\text { along the customer value proposition/interface and value network. }\end{array}$ & (Urbinati et al., 2017) \\
\hline AR72 & $\mathrm{CE}$ & Systematization of definitions of circular BMs, BM types, and potential & (Nußholz, 2017) \\
\hline
\end{tabular}




\begin{tabular}{|c|c|c|c|}
\hline & & differences from linear BMs. & \\
\hline AR73 & $\mathrm{CE}$ & $\begin{array}{l}\text { Circular BMI process including detailed information about steps, tools, } \\
\text { perspectives and participants. }\end{array}$ & (Antikainen et al., 2017) \\
\hline AR74 & $\mathrm{S}$ & $\begin{array}{l}\text { Future-Fit Business Benchmark (F2B2): framework for performance } \\
\text { assessment of BMI for sustainability with } 21 \text { key performance goals. }\end{array}$ & (Kurucz et al., 2017) \\
\hline AR75 & $\mathrm{S}$ & $\begin{array}{l}\text { Framework to support sustainability-oriented BM implementation of } \\
\text { organizations aligned with sustainability performance goals. }\end{array}$ & (Morioka et al., 2017) \\
\hline AR76 & $\mathrm{S}$ & $\begin{array}{l}\text { Systematization of } 11 \text { service design tools to support sustainability-oriented } \\
\text { BMI. }\end{array}$ & $\begin{array}{l}\text { (Prendeville and Bocken, } \\
\text { 2017) }\end{array}$ \\
\hline AR77 & $\mathrm{CE}$ & $\begin{array}{l}\text { Circularity Canvas Methodology: method for designing BMs for CE, } \\
\text { including the design of initial BM Canvas and identification of additional } \\
\text { value propositions to close loops. }\end{array}$ & (Sustainn, 2017) \\
\hline AR78 & $\mathrm{CE}$ & $\begin{array}{l}\text { Framework for evaluating the environmental value propositions of BMs for } \\
\text { CE. }\end{array}$ & (Manninen et al., 2018) \\
\hline AR79 & $\mathrm{CE}$ & $\begin{array}{l}\text { Conceptual model for the transition towards CE by introducing a } \\
\text { hierarchical structure of new BMs. }\end{array}$ & (Planing, 2018) \\
\hline AR80 & $\mathrm{CE}$ & $\begin{array}{l}\text { Circular Business Experiment Cycle: process for experimentation with } \\
\text { circular BMs. }\end{array}$ & (Bocken et al., 2018) \\
\hline AR81 & $\mathrm{CE}$ & Adapted BM Canvas for sustainability innovation. & (Bocken et al., 2018) \\
\hline AR82 & $\mathrm{S}$ & $\begin{array}{l}\text { Sustainable Value Exchange Matrix: tool to help designing sustainability- } \\
\text { oriented BMs. }\end{array}$ & (Morioka et al., 2018) \\
\hline AR83 & $\mathrm{S}$ & Value Triangle Canvas: tool to help designing sustainability-oriented BMs. & (Biloslavo et al., 2018) \\
\hline AR84 & $\mathrm{S}$ & $\begin{array}{l}\text { BM Connect methodology: to map and represent sustainable 'BM structures' } \\
\text { with the focus on the 'value flow' among actors. }\end{array}$ & (Brehmer et al., 2018) \\
\hline AR85 & $\mathrm{S}$ & $\begin{array}{l}\text { Conceptual view of hybrid businesses from the perspective of BM design } \\
\text { including four clusters of design themes and elements. }\end{array}$ & (Hahn et al., 2018) \\
\hline AR86 & $\mathrm{S}$ & $\begin{array}{l}\text { Framework of homogeneous and heterogeneous organizational value logics } \\
\text { shaped by a variety of institutional logics. }\end{array}$ & (Laasch, 2018) \\
\hline AR87 & $\mathrm{CE}$ & $\begin{array}{l}\text { Morphological box of design options for circular BMs and six BM } \\
\text { combinations for CE. }\end{array}$ & $\begin{array}{l}\text { (Lüdeke-Freund et al., } \\
\text { 2018) }\end{array}$ \\
\hline AR88 & $\mathrm{CE}$ & $\begin{array}{l}\text { Framework to integrate circular BMs and supply chain management towards } \\
\text { sustainable development. }\end{array}$ & (Geissdoerfer et al., 2018a) \\
\hline AR89 & $\mathrm{CE}$ & $\begin{array}{l}\text { Circular BM mapping tool: for mapping circular BMs and standardising the } \\
\text { representation of elements and the cycles to prolong the useful life of } \\
\text { products and close material loops. }\end{array}$ & (Nußholz, 2018) \\
\hline AR90 & $\mathrm{CE}$ & Research framework of PSS BMs for circular supply chains. & (Yang et al., 2018) \\
\hline AR91 & $\mathrm{CE}$ & $\begin{array}{l}\text { Categorizations of resource efficiency measures, BM changes and } \\
\text { implementation barriers for CE based on } 143 \text { case studies. }\end{array}$ & (Diaz Lopez et al., 2019) \\
\hline AR92 & B & $\begin{array}{l}\text { Sustainable Qualifying Criteria for Designing Circular BMs: checklist of } 24 \\
\text { characteristics that lead to enhanced sustainability potential of circular BMs. }\end{array}$ & $\begin{array}{l}\text { (de Pádua Pieroni et al., } \\
\text { 2018) }\end{array}$ \\
\hline
\end{tabular}


Business model innovation for circular economy and sustainability: a review of approaches

\section{Acknowledgements}

This article is one of the outcomes of the research project CIRCit (Circular Economy Integration in the Nordic Industry for Enhanced Sustainability and Competitiveness), which is part of the Nordic Green Growth Research and Innovation Programme (grant numbers: 83144) and supported by NordForsk, Nordic Energy Research, and Nordic Innovation. The authors would like to thank the CIRCit consortium for enriching discussions about CE and sustainability. 
Business model innovation for circular economy and sustainability: a review of approaches

\section{Highlights}

- Business model innovation for sustainability and circularity is still fragmented

- A dynamic capabilities-based view was used to organize 92 existing approaches

- There is a lack of holistic approaches covering multiple stages of innovation

- Stronger integration between circularity and sustainability is required

- A unifying research agenda for future research is proposed 